\title{
The Effects of Resveratrol in Patients with Cardiovascular Disease and Heart Failure: A Narrative Review
}

\author{
Garrison J. B. Dyck ${ }^{1}$, Pema Raj ${ }^{2}$, Shelley Zieroth ${ }^{2}$, Jason R. B. Dyck ${ }^{3}$ \\ and Justin A. Ezekowitz $1, * \mathbb{C}$ \\ 1 Canadian VIGOUR Centre, Mazankowski Alberta Heart Institute, Department of Medicine, \\ Faculty of Medicine and Dentistry, University of Alberta, Edmonton, AB T6G 2E1, Canada; dyck@ualberta.ca \\ 2 St Boniface Hospital, Department of Medicine, Rady Faculty of Health Sciences, University of Manitoba, \\ Winnipeg, MB R2H 2A6, Canada; PRaj@sbrc.ca (P.R.); SZieroth@sbgh.mb.ca (S.Z.) \\ 3 Cardiovascular Research Centre, Department of Pediatrics, Faculty of Medicine and Dentistry, \\ University of Alberta, Edmonton, AB T6G 2S2, Canada; jason.dyck@ualberta.ca \\ * Correspondence: jae2@ualberta.ca; Tel.: +780-492-0592; Fax: +780-407-6452
}

Received: 19 January 2019; Accepted: 6 February 2019; Published: 19 February 2019

\begin{abstract}
Cardiovascular disease (CVD) is the main cause of death globally and responsible for the second highest number of deaths in Canada. Medical advancements in the treatment of CVD have led to patients living longer with CVD but often progressing to another condition called heart failure (HF). As a result, HF has emerged in the last decade as a major medical concern. Fortunately, various "traditional" pharmacotherapies for HF exist and have shown success in reducing HF-associated mortality. However, to augment the treatment of patients with CVD and/or HF, alternative pharmacotherapies using nutraceuticals have also shown promise in the prevention and treatment of these two conditions. One of these natural compounds considered to potentially help treat HF and CVD and prevent their development is resveratrol. Herein, we review the clinical findings of resveratrol's ability to be used as an effective treatment to potentially help treat HF and CVD. This will allow us to gain a more fulsome appreciation for the effects of resveratrol in the health outcomes of specific patient populations who have various disorders that constitute CVD.
\end{abstract}

Keywords: resveratrol; CVD; heart failure

\section{Introduction}

Cardiovascular disease (CVD) includes various disorders of the heart and/or blood vessels such as cerebrovascular disease, peripheral artery disease, coronary artery disease (CAD), deep vein thrombosis, and congenital heart disease [1]. These conditions have varying etiology, but together and among others they constitute CVD, which is the main cause of death globally [1] and responsible for the second highest number of deaths in Canada [2]. To combat the progression of these diseases and to decrease the mortality caused by them, many advancements in technology and pharmaceutical therapies have been made in recent years [3,4]. Consequently, more Canadians are now living longer with CVD but go on to develop heart failure (HF) [5]. As a result, HF has emerged in the last decade as a major medical concern.

\subsection{Heart Failure}

In simple terms, HF can be defined as the inability of the heart to pump enough blood to the rest of the organs in the body. Of importance, the lifetime risk of developing HF for North American adults aged 45 is $20 \%$ [6] and this syndrome is expected to double over the next 1-2 
decades [7-12]. In fact, it was recently reported that HF rates are increasing in Canada and the total yearly cost of HF in Canada is approximately $\$ 2.9$ billion [13]. Various HF treatments exist and have shown success in reducing HF-associated mortality, such as implantable cardioverter defibrillators, heart transplant surgery, and numerous medications including ones that target the sympathetic nervous system ( $\beta$-adrenergic receptor blockers), the renin-angiotensin aldosterone system (angiotensin converting enzyme inhibitors and angiotensin II receptor blockers) [14], and the pacemaker current of the sinoatrial cells (ivabradine) [15]. Furthermore, medications focusing on dual inhibition of the renin-angiotensin aldosterone system (RAAS) as well as neprilysin blockade [16] (angiotensin receptor-neprilysin inhibitor) have been shown to cause a significantly greater reduction in CV-related death, HF hospitalizations, and all-cause mortality compared to only RAAS blockade [17]. However, mortality rates following diagnosis of HF remain high [18]. Adding to this problem, most existing pharmaceutical therapies that focus on treating HF with reduced ejection fraction (HF-REF) have shown little effect in treating patients with HF with preserved ejection fraction (HF-PEF) [14]. Thus, new therapies that will help treat HF, and ultimately improve the quality of life and health outcomes of these patients is needed.

\subsection{Nonconventional Therapies for HF}

In contrast to existing pharmacotherapies that largely focus on correcting neurohumoral factors that are altered in CVD and HF [14], alternative pharmacotherapies using nutraceuticals that directly target additional factors in CVD and HF progression are being considered for the prevention and treatment of these two conditions [19-21]. Indeed, certain natural compounds have been shown in preclinical studies to target the underlying causes of CVD and HF such as oxidative stress [22], inflammation [23], poor endothelial function [24], and even poor left ventricle function [25]. Therefore, these nutraceuticals may potentially target aspects of CVD and HF progression missed by, or not effectively treated with, existing pharmacotherapies. In addition, these nutraceuticals are not only being considered for independent use, but as supplements to other pre-existing HF therapies as well. While early phase trials are using these natural compounds, the goal is also to provide evidence that synthetic analogs can be made from these natural compounds in order to increase the efficacy of the compound [26]. One of these natural compounds considered to potentially help treat HF and CVD and prevent their development is resveratrol. The objective of this review is to describe the evidence of the clinical utility of resveratrol on CVD and HF treatment.

\section{Methods}

Studies were chosen by searching PubMed for publications in English dating from 2011 to August 2018. Any randomized, placebo-controlled, double-blind trials as well as systematic reviews and meta-analyses published from 2016 through 2018 were given priority in an attempt to review the most recent literature. Searches were conducted by using keywords, often in combination, such as clinical trial, RCT, resveratrol, cardiovascular disease, heart failure, atherosclerosis, inflammation, endothelium. Reference lists from previous published work were also used to find related studies. The study designs were all carefully reviewed by the authors and studies with extremely small sample sizes were mostly excluded as well as studies with listed conflicts of interest. For preclinical studies and general data on disease pathogenesis, biochemistry, and pharmacology of resveratrol, older publications were used, and the searches were not limited to post-2011 (Figure 1). 


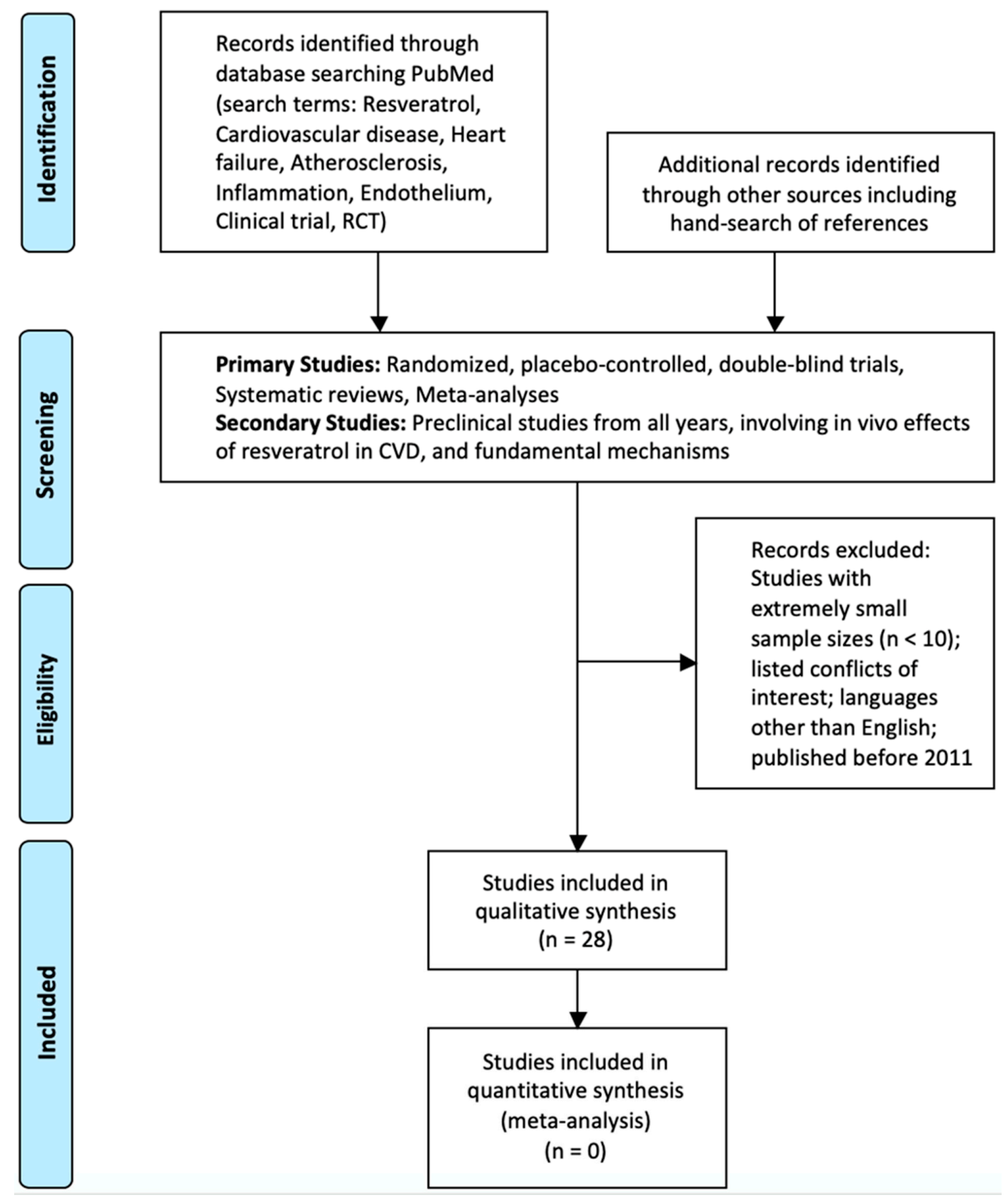

Figure 1. Flow Diagram Outlining the Selection of the Studies Involved in the Review.

\section{Resveratrol}

Resveratrol (3,5, $4^{\prime}$-trihydroxy-trans-stilbene) is a polyphenolic stilbene produced by various plants when stressed $[27,28]$. Although individuals can obtain small amounts of resveratrol in certain foods such as peanuts, grapes, berries, etc. [29], the vast majority of the research involving resveratrol has used much higher concentrations than would occur through dietary means [30]. However, even with these higher doses, the pharmacokinetic profile of resveratrol is not optimal. For example, after oral administration of resveratrol, the absorbed resveratrol is rapidly metabolized to resveratrol metabolites that are often quickly excreted [31]. In addition, studies have shown the plasma half-life of resveratrol in humans is $4-8 \mathrm{~h}$ even after doses as high as $500 \mathrm{mg} / \mathrm{kg}$ are administered [32]. As a result, plasma levels are generally low, and it remains to be determined how such low concentrations of resveratrol in the blood still have important biological effects [33]. Regardless of a complete understanding of the pharmacodynamics of resveratrol, a large number of 
studies have demonstrated the beneficial effects of resveratrol in treating CVD in animal models [33]. While the mechanisms responsible for these effects are not clear, studies have shown resveratrol causes numerous positive effects such as decreases in inflammation [34,35], increased endothelial function [36], and a reduction in oxidative stress [37]. Most relevant to this review, resveratrol has been shown to effectively treat mice with pressure-overload-induced HF by improving diastolic function, cardiac remodeling, myocardial energetics, and vascular function, as well as reducing cardiac fibrosis [38]. However, whether or not resveratrol will have an impact on humans with HF is not clearly defined.

\section{Clinical Evidence of the Effects of Resveratrol}

Due to the preclinical effects of resveratrol, many randomized clinical trials (RCTs) have been performed over the past decade in an attempt to discover if these same benefits observed in vitro and in pre-clinical studies apply to both healthy and diseased humans. However, many of these trials use highly variable protocols and doses of resveratrol [39] and suffer from small sample sizes. Moreover, as suggested by Smolgia et al., resveratrol RCTs with healthy participants often apply paradigms only appropriate for diseased participants, which leads to potentially flawed interpretations of resveratrol as ineffective [39]. These shortcomings, as well as the variable [39] and limited [40] bioavailability of resveratrol makes it difficult to interpret if the cause of an RCT with neutral results is due to dosing and/or sample size, general lack of potency of natural resveratrol (potentially fixed through chemical techniques/analogs), or simply an ineffectiveness of the compound in treating a certain human CVD regardless of potency and dose. In addition, the variation in resveratrol RCT protocols presents a difficulty when comparing trials that attempt to test the same outcomes of resveratrol supplementation.

\subsection{Effects on Factors Related to the Pathogenesis of Atherosclerosis and Coronary Artery Disease}

Atherosclerosis is often seen as a chronic low-grade inflammatory condition with a complex pathogenesis involving endothelial dysfunction, lipoprotein build up and oxidation, pro-inflammatory cytokines, and various other factors [41,42]. Atherosclerosis is also the main cause of coronary artery disease (CAD) [42], which is the most common etiology of patients with HF in developed nations [43]. Thus, to assess the efficacy of resveratrol in treating patients with HF, many clinical trials attempt to measure the effects of resveratrol on the factors related to the pathogenesis of atherosclerosis and CAD, including effects on inflammation, lipoprotein and cholesterol metabolism, and endothelial function (Table 1; Figure 2). 
Table 1. Summary of Studies Involved in Coronary Artery Disease.

\begin{tabular}{|c|c|c|c|c|c|c|}
\hline Study Done by & Study Design & Subjects & Dose and Treatment Period & Area of Interest & $\begin{array}{c}\text { Primary or Key Exploratory } \\
\text { Outcomes }\end{array}$ & Secondary Outcomes \\
\hline \multicolumn{7}{|c|}{ Atherosclerosis and Coronary Artery Disease } \\
\hline \multicolumn{7}{|c|}{ Endothelial Function } \\
\hline Fujitaka et al., 2011 [44] & Randomized & 34 patients with metabolic syndromes & $\begin{array}{l}100 \mathrm{mg} \text { of resveratrol (Longvinex; } \\
\text { contains reseveratrol but also vitamin } \\
\text { D3, quercetin, and rice bran phytate) } \\
\text { daily for } 3-6 \text { months }\end{array}$ & $\begin{array}{l}\text { Effects of resveratrol on the } \\
\text { endothelial function of } \\
\text { metabolically } \\
\text { unhealthy patients }\end{array}$ & $\begin{array}{l}\text { Increase in flow mediated dilation } \\
\text { (FMD; i.e., endothelial } \\
\text { function improvements). }\end{array}$ & $\begin{array}{l}\text { No effect on body composition, lipid profile, } \\
\text { interleukin-6(IL-6) and high-sensitive } \\
\text { C-reactive protein (hsCRP). }\end{array}$ \\
\hline Imamura et al., 2017 [45] & $\begin{array}{l}\text { Double blind, } \\
\text { randomized, } \\
\text { placebo-controlled }\end{array}$ & 50 adults with type 2 diabetes mellitus & $\begin{array}{c}100 \mathrm{mg} \text { of resveratrol (BHN Corporation } \\
\text { (Tokyo) as resveratrol- } \varepsilon \text { ) daily for } \\
12 \text { weeks }\end{array}$ & $\begin{array}{l}\text { Effects of resveratrol on } \\
\text { arterial stiffness }\end{array}$ & $\begin{array}{l}\text { Decrease in arterial stiffness } \\
\text { (measured by decrease in } \\
\text { cardio-ankle vascular } \\
\text { index; CAVI). }\end{array}$ & $\begin{array}{l}\text { No effects on fasting plasma glucose, } \\
\text { HbAlc, total cholesterol, triglycerides, } \\
\text { high-density lipoproteins (HDL) cholesterol } \\
\text { (HDL-C) and low-density lipoproteins } \\
\text { (LDL) cholesterol (LDL-C). } \\
\text { Improved systolic blood pressure but no } \\
\text { effect on diastolic blood pressure. }\end{array}$ \\
\hline Marques et al., 2018 [46] & $\begin{array}{c}\text { Double blind, } \\
\text { cross-over, } \\
\text { randomized, } \\
\text { placebo-controlled }\end{array}$ & 24 hypertensive adults & $\begin{array}{l}300 \mathrm{mg} \text { of resveratrol (Bioderm } \\
\text { Pharmacy (Rio de Janeiro, Brazil) } \\
\text { once daily }\end{array}$ & $\begin{array}{l}\text { Cardiovascular effects of acute } \\
\text { resveratrol dose }\end{array}$ & $\begin{array}{c}\text { Improved endothelial function } \\
\text { (FMD improvements); no effect on } \\
\text { peripheral blood pressure (BP), } \\
\text { Augmentation Index, and aortic } \\
\text { systolic BP (SBP). }\end{array}$ & \\
\hline Wong et al., 2013 [47] & $\begin{array}{c}\text { Randomized, } \\
\text { placebo-controlled, } \\
\text { double-blind } \\
\text { crossover }\end{array}$ & 28 obese, otherwise healthy, adults & $75 \mathrm{mg}$ daily of resveratrol for 6 weeks & $\begin{array}{l}\text { Effects of resveratrol on } \\
\text { endothelial functioning of } \\
\text { obese patients }\end{array}$ & $\begin{array}{l}\text { Increase in endothelial function } \\
\text { (FMD improvements). } \\
\text { No effect on BP or } \\
\text { arterial compliance. }\end{array}$ & \\
\hline \multicolumn{7}{|c|}{ Lipoprotein and Cholesterol } \\
\hline Gilemann et al., 2013 [48] & $\begin{array}{c}\text { Randomized } \\
\text { double-blind } \\
\text { placebo-controlled }\end{array}$ & $\begin{array}{l}27 \text { physically inactive aged } \\
\text { (mean age }=65 \pm 1 \text { year) men }\end{array}$ & $\begin{array}{l}250 \mathrm{mg} \text { of resveratrol (Fluxome Inc., } \\
\text { Stenlose, Denmark) daily for } 8 \text { weeks }\end{array}$ & $\begin{array}{l}\text { Effect of resveratrol with } \\
\text { exercise on } \\
\text { cardiovascular health }\end{array}$ & $\begin{array}{c}\text { Blunted decreases in total } \\
\text { cholesterol, and ratio of total } \\
\text { cholesterol//HDL levels following } \\
\text { exercise. } \\
\text { Blunted the phosphorylation of } \\
\text { endothelial nitric oxide (NO) } \\
\text { synthase (eNOS) following } \\
\text { exercise. } \\
\text { Blunted increase of eNOS } \\
\text { following exercise. } \\
\text { Decreased maximum oxygen } \\
\text { uptake after exercise. }\end{array}$ & $\begin{array}{l}\text { Blunted mean arterial pressure decreases } \\
\text { following exercise. } \\
\text { No effect on blood glucose, body mass } \\
\text { index (BMI), protein expression in skeletal } \\
\text { muscle, including for silent information } \\
\text { regulator factor } 2 \text { related enzyme } 1 \text { (SRTT1). } \\
\text { Blunted effects on increases in prostacyclin } \\
\text { (PGI2) after exercise. }\end{array}$ \\
\hline
\end{tabular}


Table 1. Cont.

\begin{tabular}{|c|c|c|c|c|c|c|}
\hline $\begin{array}{l}\text { Haghighatdoost et al., } 2018 \\
\text { [49] }\end{array}$ & $\begin{array}{l}\text { Systematic review } \\
\text { and meta-analysis }\end{array}$ & $\begin{array}{l}763 \text { adults included in total cholesterol } \\
\text { analysis, } 728 \text { adults included in LDL-C } \\
\text { analysis, } 777 \text { adults included in HDL-C } \\
\text { analysis, and } 921 \text { in serum } \\
\text { triglyceride analysis. } \\
\end{array}$ & $\begin{array}{l}\text { Resveratrol doses ranged from } 10 \\
\mathrm{mg} / \text { day to } 1500 \mathrm{mg} / \text { day with treatment } \\
\text { periods ranging from } 4 \text { to } 24 \text { weeks }\end{array}$ & $\begin{array}{l}\begin{array}{c}\text { Effects of resveratrol on lipid } \\
\text { profile }\end{array}\end{array}$ & $\begin{array}{l}\text { Decreased total cholesterol in } \\
\text { subjects with normal BMI, but not } \\
\text { those overweight or obese; } \\
\text { No effect on LDL-C or HDL-C. }\end{array}$ & $\begin{array}{l}\text { Increase in plasma triglyceride levels, this } \\
\text { effect became insignificant when one study } \\
\text { (Zortea et al. [500) was removed from the } \\
\text { meta-analysis). }\end{array}$ \\
\hline Heebøll et al., 2016 [51] & $\begin{array}{l}\text { Double blind, } \\
\text { randomized, } \\
\text { placebo-controlled }\end{array}$ & $\begin{array}{l}28 \text { adults with non-alcoholic fatty } \\
\text { liver disease }\end{array}$ & $\begin{array}{l}1500 \mathrm{mg} \text { of resveratrol (Evolva SA (Basel, } \\
\text { Switzerland) daily for } 6 \text { months }\end{array}$ & $\begin{array}{l}\text { Effects of resveratrol on } \\
\text { symptoms associated with } \\
\text { non-alcoholic fatty } \\
\text { liver disease }\end{array}$ & $\begin{array}{l}\text { No changes in plasma glucose, } \\
\text { insulin, lipid profile or homeostatic } \\
\text { model assessment (HOMA) index. }\end{array}$ & $\begin{array}{l}\text { No effect of BMI, weight, waist-hip ratio, } \\
\text { SIRT1 or AMP-activated protein kinase } \\
\text { (AMPK) activity. }\end{array}$ \\
\hline Poulsen et al., 2013 [52] & $\begin{array}{c}\text { Randomized, } \\
\text { placebo-controlled, } \\
\text { double blinded }\end{array}$ & 24 obese, otherwise healthy, males & $\begin{array}{l}500 \mathrm{mg} \text { of resveratrol (Fluxome Inc., } \\
\text { Stenlose, Denmark) daily for } 4 \text { weeks }\end{array}$ & $\begin{array}{l}\text { Effects of high dose } \\
\text { of resveratrol }\end{array}$ & $\begin{array}{l}\text { No effects on lipid oxidation, } \\
\text { adiponectin or insulin, } \\
\text { body composition. }\end{array}$ & $\begin{array}{l}\text { No effect on BP, lipid profile, liver function, } \\
\text { SIRT1, AMPK pathways or } \\
\text { inflammatory biomarkers. }\end{array}$ \\
\hline $\begin{array}{c}\text { Tomé-Carneiro J et al., } 2012 \\
\text { [53] }\end{array}$ & $\begin{array}{l}\text { Triple-blind, } \\
\text { randomized, } \\
\text { placebo-controlled }\end{array}$ & $\begin{array}{l}75 \text { adult patients given primary prevention } \\
\text { of CVD }\end{array}$ & $\begin{array}{l}370 \mathrm{mg} \text { capsule with } 350 \mathrm{mg} \text { Stilvid@( }(23 \\
\text { mg resveratrol/gram and other minor } \\
\text { grape stilbenes) daily and } 20 \mathrm{mg} \\
\text { magnesium stearate and } \mathrm{SiO}_{2} \text { (inactive) } \\
\text { for } 6 \text { months }\end{array}$ & $\begin{array}{l}\text { Cardiovascular effects } \\
\text { of resveratrol }\end{array}$ & $\begin{array}{l}\text { Decrease in apolipoprotein B-100 } \\
\text { (ApoB) and oxidized LDL } \\
\text { (LDL-ox) plasma levels, cannot be } \\
\text { ruled out if resveratrol had } \\
\text { a synergistic effect with other } \\
\text { grape polyphenols in the capsule. }\end{array}$ & \\
\hline Zare Javid et al., 2017 [54] & $\begin{array}{c}\text { Randomized } \\
\text { double-blind, } \\
\text { placebo-controlled }\end{array}$ & 43 adults with type 2 diabetes & $\begin{array}{l}480 \mathrm{mg} \text { of resveratrol [(ingredients: } \\
\text { Polygonum cuspidatum extract }(72 \%) \\
\text { with at least } 60 \% \text { trans-resveratrol, } \\
\text { gelatin, microcrystalline cellulose (filler), } \\
\text { and magnesium stearate) from Herbafit] } \\
\text { for } 4 \text { weeks }\end{array}$ & Metabolic effects of resveratrol & $\begin{array}{l}\text { Increased insulin resistance. } \\
\text { No effect on plasma levels of } \\
\text { fasting glucose or triglycerides. }\end{array}$ & \\
\hline Zortea et al., 2016 [50] & $\begin{array}{c}\text { Randomized } \\
\text { double-blind, } \\
\text { placebo-controlled }\end{array}$ & 19 adult men with schizophrenia & $\begin{array}{l}200 \mathrm{mg} \text { of resveratrol (trans-resveratrol, } \\
98 \% \text { purified) daily for } 30 \text { days }\end{array}$ & $\begin{array}{l}\text { Cardiovascular effects of } \\
\text { resveratrol }\end{array}$ & $\begin{array}{l}\text { Decrease in triglyceride plasma } \\
\text { levels. } \\
\text { No effects on serum glucose or } \\
\text { body weight, BMI, and waist } \\
\text { circumference. }\end{array}$ & \\
\hline \multicolumn{7}{|c|}{ Inflammatory Effects } \\
\hline Olesen et al., 2014 [55] & $\begin{array}{c}\text { Randomized, } \\
\text { double-blinded, } \\
\text { placebo-controlled }\end{array}$ & 43 healthy, physically inactive, elderly, men & $\begin{array}{l}250 \mathrm{mg} \text { of resveratrol (Fluxome Inc., } \\
\text { Stenlose, Denmark) daily with and } \\
\text { without exercise for } 8 \text { w weeks }\end{array}$ & $\begin{array}{l}\text { Effects of resveratrol on } \\
\text { skeletal muscle inflammation } \\
\text { both alone and with exercise }\end{array}$ & $\begin{array}{l}\text { No anti-inflammatory effect } \\
\text { without exercise, including no } \\
\text { plasma level changes of c-reactive } \\
\text { protein (CRP), IL-6, or tumor } \\
\text { necrosis factor (TNF) } \alpha . \\
\text { A blunting on anti-inflammatory } \\
\text { effect with exercise training. }\end{array}$ & $\begin{array}{l}\text { No endurance effects, effects on SIRTI or } \\
\text { AMPK pathways but an overall decrease in } \\
\text { acetylation level. } \\
\text { No effect on protein content of skeletal } \\
\text { muscle, or protein carbonylation. }\end{array}$ \\
\hline
\end{tabular}


Table 1. Cont.

\begin{tabular}{|c|c|c|c|c|c|c|}
\hline $\begin{array}{c}\text { Tomé-Carneiro J et al., } 2013 \\
{[56]}\end{array}$ & $\begin{array}{c}\text { Triple-blind, } \\
\text { randomized, } \\
\text { placebo-controlled }\end{array}$ & 75 stable CAD patients & $\begin{array}{l}370 \mathrm{mg} \text { capsule with } 350 \mathrm{mg} \text { Stilvid@( } 23 \\
\mathrm{mg} \text { resveratrol/gram) daily and } 20 \mathrm{mg} \\
\text { magnesium stearate and } \mathrm{SiO}_{2} \text { (inactive) } \\
\text { for } 1 \text { year }\end{array}$ & $\begin{array}{l}\text { Cardiovascular effects } \\
\text { of resveratrol }\end{array}$ & $\begin{array}{c}\text { Increase in serum } \\
\text { adiponectin levels. } \\
\text { Decrease in plasminogen activator } \\
\text { inhibitor-1 (PAI-1) plasma levels. } \\
\text { General suppression of peripheral } \\
\text { blood mononuclear cell (PBMC) } \\
\text {-mediated inflammatory pathway, } \\
\text { however no changes in levels of } \\
\text { TNF } \alpha, \text { IL-6, or IL-10. }\end{array}$ & \\
\hline $\begin{array}{c}\text { Tomé-Carneiro J et al., } 2012 \\
{[57]}\end{array}$ & $\begin{array}{c}\text { Triple-blind, } \\
\text { randomized, } \\
\text { placebo-controlled }\end{array}$ & $\begin{array}{l}75 \text { adults undergoing primary prevention } \\
\text { for CVD }\end{array}$ & $8 \mathrm{mg}$ of resveratrol daily for 1 year & $\begin{array}{l}\text { Inflammatory effects } \\
\text { of resveratrol }\end{array}$ & $\begin{array}{c}\text { Decrease in hsCRP, TNF } \alpha, \\
\text { plasminogen activator inhibitor } \\
\text { type } 1 \text {, or IL-6/IL-10 ratio. } \\
\text { Increase in IL-10 and adiponectin } \\
\text { plasma levels. } \\
\text { Decrease in soluble intercellular } \\
\text { adhesion molecule plasma levels. }\end{array}$ & \\
\hline \multicolumn{7}{|c|}{ Various Measures Relating to Atherosclerosis } \\
\hline Agarwal et al., 2013 [58] & $\begin{array}{c}\text { Double blind, } \\
\text { randomized, } \\
\text { placebo-controlled }\end{array}$ & 41 healthy adult subjects & $\begin{array}{l}\text { 400mg trans-resveratrol ( } 98 \% \text { pure, } \\
\text { sourced from Polygonum Cuspidatum), } \\
\text { 400mg grape-skin extract, and } 100 \mathrm{mg} \\
\text { quercetin daily for } 4 \text { weeks }\end{array}$ & $\begin{array}{l}\text { Effects of resveratrol on } \\
\text { endothelial function and } \\
\text { atherosclerosis }\end{array}$ & $\begin{array}{l}\text { Reduction in mRNA expression of } \\
\text { vascular cell adhesion molecule } \\
\text { (VCAM), intercellularad adhesion } \\
\text { molecule } 1 \text { (ICAM-1) and IL-8. } \\
\text { Reduction in plasma } \\
\text { interferon (IFN)- } \gamma \text {. } \\
\text { No effect on II- } 1 \text {, IL- } 6 \text {, and TNF } \alpha \\
\text { plasma levels, however overall } \\
\text { endothelial cell cytokine } \\
\text { activation decreased. }\end{array}$ & Reduction in fasting insulin concentrations. \\
\hline Bhatt et al., 2012 [59] & $\begin{array}{l}\text { Open-label, } \\
\text { randomized, } \\
\text { controlled }\end{array}$ & 57 male adults with type 2 diabetes mellitus & $\begin{array}{l}250 \mathrm{mg} \text { of resveratrol (Biofort; Biotivia } \\
\text { Bioceuticals International, New York, } \\
\text { NY, USA) daily for } 3 \text { months }\end{array}$ & $\begin{array}{l}\text { Cardiovascular and metabolic } \\
\text { effects of resveratrol }\end{array}$ & $\begin{array}{l}\text { Decreases in hemoglobin A1c } \\
\text { (HbA1c), SBP, total cholesterol, } \\
\text { and total protein. }\end{array}$ & $\begin{array}{l}\text { No significant change in LDL plasma levels } \\
\text { or body weight. }\end{array}$ \\
\hline Chen et al., 2015 [60] & $\begin{array}{c}\text { Double blind, } \\
\text { randomized, } \\
\text { placebo-controlled }\end{array}$ & $\begin{array}{l}60 \text { adults with non-alcoholic fatty } \\
\text { liver disease }\end{array}$ & $\begin{array}{l}300 \mathrm{mg} \text { of resveratrol (brand not } \\
\text { provided) for } 3 \text { months }\end{array}$ & Metabolic effects of resveratrol & $\begin{array}{l}\text { Decreased LDL-C and total } \\
\text { cholesterol, glucose, or } \\
\text { inflammatory cytokines. } \\
\text { Improved insulin resistance. } \\
\text { Increased adiponectin levels. }\end{array}$ & \\
\hline Huang et al., 2016 [61] & $\begin{array}{l}\text { Systematic review } \\
\text { and meta-analysis }\end{array}$ & 681 adults & $\begin{array}{l}\text { Resveratrol doses ranging from } 8 \\
\mathrm{mg} / \text { day to } 3000 \mathrm{mg} / \text { day } \\
\text { With a duration of treatment ranging } \\
\text { from } 2 \text { weeks to } 6 \text { months }\end{array}$ & $\begin{array}{l}\text { Effects of resveratrol on } \\
\text { cardiovascular disease risk } \\
\text { factors in overweight and } \\
\text { obese adults }\end{array}$ & $\begin{array}{l}\text { Decreases in blood plasma total } \\
\text { cholesterol levels (no change in } \\
\text { LDL-C and HDL-C levels } \\
\text { were observed). } \\
\text { Decreases in SBP and no effect } \\
\text { on DBP. } \\
\text { No effect on fasting glucose levels, } \\
\text { except when stratifified for patients } \\
\text { with metabolic syndrome. } \\
\text { No effect in inflammatory } \\
\text { biomarkers IL-6 and TNF } \alpha \text { plasma } \\
\text { levels. }\end{array}$ & $\begin{array}{l}\text { No effect on body weight. } \\
\text { In higher resveratrol doses (more than or } \\
\text { exactly } 300 \mathrm{mg} \text { per day) significant } \\
\text { decreases in SBP, fasting insulin, } \\
\text { fasting glucose, and total cholesterol } \\
\text { was seen. } \\
\text { In lower doses (less than } 300 \mathrm{mg} \text { daily) } \\
\text { reductions in HbAlc were observed. } \\
\text { Decreases in total cholesterol, glucose, } \\
\text { and HbAlc were more significant for } \\
\text { participants who took resveratrol for more } \\
\text { or equal to } 3 \text { months. } \\
\text { Decreases in fasting insulin plasma levels } \\
\text { were more significant for patients who took } \\
\text { resveratrol for less than } 3 \text { months. }\end{array}$ \\
\hline
\end{tabular}


Table 1. Cont

\begin{tabular}{|c|c|c|c|c|c|c|}
\hline Macedo et al., 2015 [62] & $\begin{array}{l}\text { Double-blind, } \\
\text { placebo-controlled } \\
\text { study }\end{array}$ & 60 healthy adults & $\begin{array}{l}100 \mathrm{mg} \text { of resveratrol (Polygonum } \\
\text { cuspidatum provided by Farmel } \\
\text { Pharmacy (São Paulo, SP, Brazil)) daily } \\
\text { for } 3 \text { months with routine fitness tests }\end{array}$ & $\begin{array}{l}\text { Effects of resveratrol of } \\
\text { participants undergoing } \\
\text { a fitness test }\end{array}$ & $\begin{array}{l}\text { No effect on total lipid profile. } \\
\text { Reduction in IL-6 and TNF } \alpha \\
\text { plasma levels. } \\
\text { No effect on IL-8 plasma levels. } \\
\text { No antioxidant effects observed. }\end{array}$ & \\
\hline $\begin{array}{l}\text { Mendez-del Villar et al., } \\
\text { 2012 [63] }\end{array}$ & $\begin{array}{l}\text { Double blind, } \\
\text { randomized, } \\
\text { placebo-controlled }\end{array}$ & 24 adults with metabolic syndromes & $1500 \mathrm{mg}$ of resveratrol daily for 90 days & $\begin{array}{l}\text { Cardiovascular and metabolic } \\
\text { effects of resveratrol }\end{array}$ & $\begin{array}{c}\text { Decreases in total weight, BMI, } \\
\text { fat mass, and waist circumference. } \\
\text { Decreases in total insulin secretion } \\
\text { and area under the curve (AUC) } \\
\text { of insulin. }\end{array}$ & \\
\hline Millatru et al., 2013 [64] & $\begin{array}{l}\text { Randomized, } \\
\text { double-blinded, } \\
\text { active-controlled, } \\
\text { parallel }\end{array}$ & 87 adults with stable angina pectoris & $\begin{array}{l}20 \mathrm{mg} \text { of resveratrol daily or } 20 \mathrm{mg} \text { of } \\
\text { resveratrol daily and } 112 \mathrm{mg} \text { of calcium } \\
\text { fructoborate (CF) daily (shown to slow } \\
\text { down the breakdown of resveratrol in } \\
\text { the digestive system) }\end{array}$ & $\begin{array}{l}\text { Cardiovascular effects of } \\
\text { resveratrol alone and in } \\
\text { combination with } \mathrm{CF}\end{array}$ & $\begin{array}{c}\text { In combination with CF, decreased } \\
\text { N-terminal pro b-type natriuretic } \\
\text { peptide (NT-proBNP) } \\
\text { plasma levels. } \\
\text { Decreased plasma levels of total } \\
\text { cholesterol and triglycerides. } \\
\text { Decreased number of } \\
\text { angina episodes. }\end{array}$ & $\begin{array}{l}\text { Less effective than CF alone in decreasing } \\
\text { LDL plasma levels and increasing HDL } \\
\text { plasma levels. }\end{array}$ \\
\hline S. Bo et al., 2016 [65] & $\begin{array}{l}\text { Double blind, } \\
\text { randomized, } \\
\text { placebo-controlled }\end{array}$ & 179 adults with type 2 diabetes & $\begin{array}{l}\text { Either } 500 \mathrm{mg} \text { or } 40 \mathrm{mg} \text { of resveratrol } \\
\text { (provided by Biotivia Bioceuticals } \\
\text { (International SrLL Italy) daily for } 6 \\
\text { months }\end{array}$ & $\begin{array}{l}\text { Cardiovascular effects of } \\
\text { resveratrol }\end{array}$ & No changes in CRP levels. & $\begin{array}{l}\text { Slight increase in plasma levels of total } \\
\text { cholesterol and triglycerides. } \\
\text { No changes in BMI, waist circumference, } \\
\text { arterial blood pressure, IL-6, fasting glucose, } \\
\text { HbAlc, and insulin. }\end{array}$ \\
\hline S. Bo et al., 2013 [66] & $\begin{array}{c}\text { Double blind, } \\
\text { randomized, } \\
\text { placebo-controlled }\end{array}$ & 49 healthy adult smokers & $\begin{array}{l}500 \mathrm{mg} \text { of resveratrol (provided by } \\
\text { Biotivia Bioceuticals (International SrL, } \\
\text { Italy)) daily for } 30 \text { days }\end{array}$ & $\begin{array}{l}\text { Anti-inflammatory and } \\
\text { antioxidant effects of } \\
\text { resveratrol }\end{array}$ & Reduction in CRP plasma levels. & $\begin{array}{l}\text { Reduction in triglyceride plasma levels. } \\
\text { Increase in Total Antioxidant Status. }\end{array}$ \\
\hline Sahebkar et al., 2013 [67] & $\begin{array}{l}\text { Systematic review } \\
\text { Meta-analysis }\end{array}$ & 600 adults & $\begin{array}{l}\text { Resveratrol doses ranged from } 8 \\
\mathrm{mg} / \text { day to } 1500 \mathrm{mg} / \text { day. Treatment } \\
\text { periods ranged from } 60 \text { days to one year. }\end{array}$ & $\begin{array}{l}\text { Effects of resveratrol on CRP } \\
\text { plasma levels and other } \\
\text { cardiovascular risk factors }\end{array}$ & $\begin{array}{l}\text { No effect on total cholesterol } \\
\text { plasma levels. } \\
\text { No effect on plasma triglyceride or } \\
\text { glucose concentrations. } \\
\text { Slightly reduced HDL-C plasma } \\
\text { concentrations. }\end{array}$ & $\begin{array}{l}\text { No effect on CRP plasma levels. } \\
\text { No effect on BP. }\end{array}$ \\
\hline $\begin{array}{l}\text { Van der Made et al., } 2015 \\
\text { [68] }\end{array}$ & $\begin{array}{l}\text { Double blind, } \\
\text { randomized, } \\
\text { placebo-controlled, } \\
\text { cross over }\end{array}$ & 45 overweight or slightly obese adults & $\begin{array}{l}150 \mathrm{mg} \text { of resveratrol (resVida) daily for } \\
4 \text { weeks, followed by } 4 \text { weeks wash out, } \\
\text { and another } 4 \text { weeks of supplementation }\end{array}$ & $\begin{array}{l}\text { Cardiovascular and metabolic } \\
\text { effects of resveratrol }\end{array}$ & $\begin{array}{l}\text { No differences in serum } \\
\text { apolipoprotein A-I (apoA-I) or } \\
\text { apoB-100 concentrations. }\end{array}$ & $\begin{array}{l}\text { No effect on the levels of metabolic risk } \\
\text { factors in plasma (including LDL and HDL). } \\
\text { Increase in diastolic BP and heart rate. } \\
\text { No effect on mean arterial pressure, SBP, or } \\
\text { insulin concentrations. } \\
\text { No effect on biomarkers of inflammation } \\
\text { (hsCRP, IL-6, E-selectin, thromobomodulin, } \\
\text { P-selectin or TNF } \alpha \text { ). } \\
\text { No effect on ICAM-3, soluble ICAM-1 } \\
\text { (sICAM-1), soluble vascular cell adhesion } \\
\text { molecule-1 (sVCAM-1) pplasma levels. }\end{array}$ \\
\hline
\end{tabular}


Table 1. Cont.

\begin{tabular}{|c|c|c|c|c|c|}
\hline Timmers et al., 2011 [69] & $\begin{array}{c}\text { Randomized } \\
\text { double-blind } \\
\text { crossover design }\end{array}$ & 11 obese, but otherwise healthy, patients & $\begin{array}{l}150 \mathrm{mg} \text { of } 99 \% \text { pure trans-resveratrol } \\
\text { (resVida'T }{ }^{\mathrm{TM}} \text { ) daily for } 30 \text { days }\end{array}$ & $\begin{array}{l}\text { Effects of resveratrol on } \\
\text { metabolism }\end{array}$ & 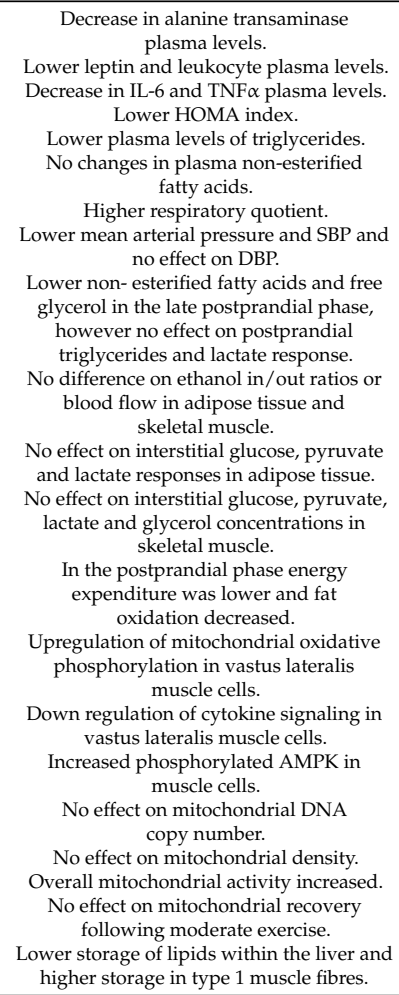 \\
\hline $\begin{array}{c}\text { Tomé-Carneiro J et al., } 2013 \\
\text { [70] }\end{array}$ & $\begin{array}{c}\text { Triple-blind, } \\
\text { randomized, } \\
\text { placebo-controlled }\end{array}$ & $\begin{array}{l}35 \text { adult males with type } 2 \text { diabetes or } \\
\text { hypertension }\end{array}$ & $\begin{array}{l}370 \mathrm{mg} \text { capsule with } 350 \mathrm{mg} \mathrm{Stilvid} \circledast(23 \\
\mathrm{mg} \text { resveratrol/gram and other minor } \\
\text { grape stillbenes) daily and } 20 \mathrm{mg} \\
\text { magnesium stearate and } \mathrm{SiO}_{2} \text { (inactive) } \\
\text { for } 1 \text { year }\end{array}$ & $\begin{array}{l}\text { Cardiovascular effects } \\
\text { of resveratrol }\end{array}$ & $\begin{array}{c}\text { A downregulation of } \\
\text { inflammatory cytokines. } \\
\text { No effect on SBP, DBP, weight, lipid profile, } \\
\text { glucose plasma levels, HbA1C, hsCRP, } \\
\text { adiponectin, PAI-1, TNF } \alpha \text {, and II-10. } \\
\text { Decrease in I- I-6 plasma levels. } \\
\text { Modifies microRNA (miR)s involved in } \\
\text { inflammatory modulation. }\end{array}$ \\
\hline Yoshino et al., 2012 [71] & $\begin{array}{c}\text { Randomized, } \\
\text { double-blind, } \\
\text { placebo-controlled }\end{array}$ & $\begin{array}{l}29 \text { non-obese, normal glucose } \\
\text { tolerant, woman }\end{array}$ & $\begin{array}{c}75 \mathrm{mg} \text { of resveratrol } 99 \% \text { pure } \\
\text { trans-resveratrol [(resvidida' from DSM } \\
\text { Nutritional Products, Ltd.)] a day for } \\
12 \text { weeks }\end{array}$ & $\begin{array}{l}\text { Effects of resveratrol on } \\
\text { metabolically } \\
\text { healthy individuals }\end{array}$ & $\begin{array}{l}\text { No effect on body composition, insulin } \\
\text { sensitivity, AMPK or SIRT1 pathways. }\end{array}$ \\
\hline
\end{tabular}




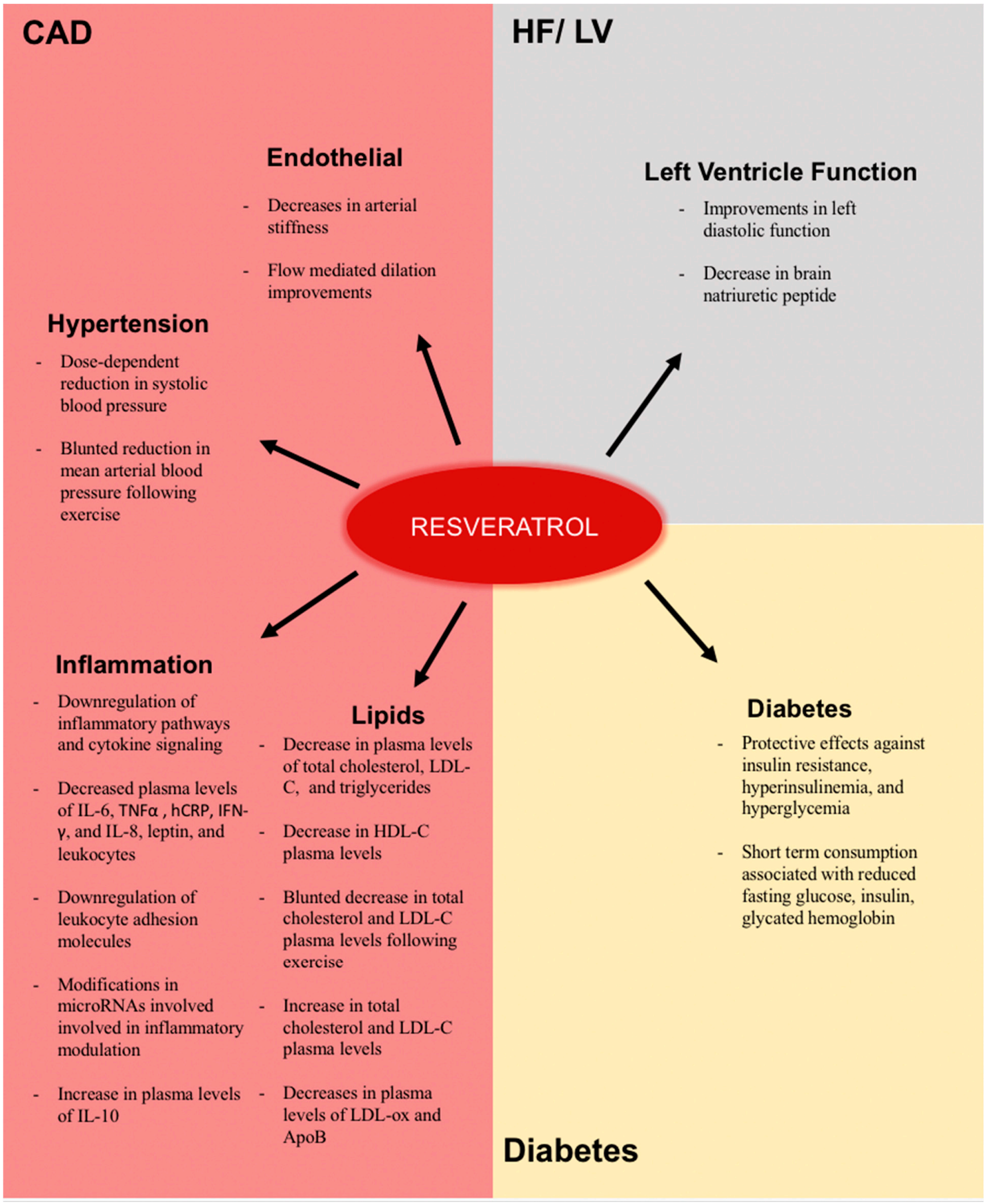

Figure 2. Summary of the findings from the clinical studies involving resveratrol. The key findings in the studies using resveratrol in different patient populations are summarized. The three main subgroups of disease conditions are indicated by Coronary Artery Disease (CAD), Heart Failure (HF)/Left Ventricular (LV) Function, and diabetes and the effects on different biological entities are indicated.

\subsection{Effects in Inflammation}

The link between vascular inflammation and risk of CVD, most notably hypertension and atherosclerosis, is well documented [72]. In atherosclerosis, the beginning stages of the development of an atherosclerotic lesion are characterized by endothelial cells beginning to express selective adhesion molecules such as vascular cell adhesion molecule-1 (VCAM-1) that promote attachment of leukocytes to the endothelium [41]. This activity is the most pronounced in damaged areas of 
the endothelium with disturbed flow and a low production of nitric oxide (NO) [73]. In addition, the smooth muscle cells (SMCs) in these damaged areas may produce proteoglycans that attach to lipoproteins, promote their oxidation, and increase the adhesion of leukocytes to the lesions of the arterial walls [74]. The chemically attracted leukocytes, including lymphocytes [75] and monocytes [76], then enter the intima and stimulate a local inflammatory response [41]. Stimulation factors also causes monocytes to develop into macrophage foam cells [77] and inflammatory cytokines released by T-cells promote the smooth muscle cells of the endothelium [78] to eventually form a thick extracellular matrix of SMCs and fibrin [79]. Given this role of inflammation in atherosclerosis, pro-inflammatory cytokines are often used as biomarkers to monitor changes in atherosclerosis risk and consequently the prognosis of HF after supplementation of a potential cardio-protective drug [41]. Common biomarkers related to the inflammatory response measured in resveratrol clinical trials include interleukin (IL)-6, tumor necrosis factor (TNF) $\alpha$, c-reactive protein (CRP), Intercellular Adhesion Molecule 1 (ICAM-1), $P$ selectin, and E selectin [41]. Other inflammatory cytokines also involved with cardiac diseases used in resveratrol RCTs to assess risk of atherosclerosis and HF include IL-8; mostly as a marker of negative effects) and IL-10 (anti-inflammatory and a marker of positive effects) [80].

Due to the detrimental role inflammation plays in CVDs and HF, the vast amount of evidence in cell and animal models that show the anti-inflammatory effects of resveratrol [81-86] has prompted various clinical trials testing if the compound exerts anti-inflammatory effects in humans. As described by Poulsen et al., a proposed mechanism for the potential anti-inflammatory effects of resveratrol in humans is an increased activation of the silent information regulator factor 2 related enzyme 1 (SIRT1) [87]. SIRT1 had been shown in vitro to protect against HF induced inflammation [88] and cells from mice with a SIRT1 knockout show increased pro-inflammatory cytokine levels [89]. Also, resveratrol is a known activator of SIRT1 in animals [90] and cultured cells [91,92]. Therefore, it follows that resveratrol could potentially decrease inflammation in humans by increasing the activity of SIRT1. However, multiple other potential anti-inflammatory mechanisms of resveratrol, including some that may be linked to SIRT1 activation, have been proposed such as a suppression of cytokine signaling [93], a suppression of major pro-inflammatory kinase expression [93], and an increase in levels of anti-inflammatory eicosanoid precursors [94]. However, the results of the clinical trials testing the effects of resveratrol on inflammation have been highly variable. Some clinical trials have found a decrease in plasma levels of inflammatory cytokines following resveratrol supplementation, including a decrease in the cytokines IL-6 [57,62,65,69,70], TNF $\alpha[57,60,62,69]$, high-sensitive CRP (hsCRP) or CRP [57,65,66], plasma interferon (IFN)- $\gamma$ [58], and IL-8 [58] that could be linked to increased SIRT1 activity. Moreover, in a study performed by Timmers et al., $150 \mathrm{mg}$ of resveratrol daily supplementation for 30 days resulted in modest reductions in plasma levels of leptin, leukocytes, and the previously mentioned IL- 6 and TNF $\alpha$ in obese adults [69]. After genetic analysis, it was revealed that resveratrol downregulated inflammatory pathways and cytokine signaling [69]. Other studies have also found that resveratrol causes a downregulation of leukocyte adhesion molecules [57,58], modifications in microRNAs involved in modulating inflammation [56], and increased plasma levels of the anti-inflammatory cytokine IL-10 [57]. Given that these studies used highly variable resveratrol doses, treatment periods, and types of participants, these findings suggest that resveratrol given at various doses for varying treatment periods decreases inflammation in both healthy and diseased humans. However, numerous studies have also shown no effect of resveratrol on plasma levels of molecules involved in the inflammatory response, including IL-6 [44,52,55,58,61,68], TNF $\alpha$ [52,55,58,61,68,95], CRP [44,55,67,68,95], IL-8 [62], IL-1B [58], vascular cell adhesion molecules (VCAM) [68], P-selectin [68], and E-selectin [68]. It should be mentioned that studies showing lack of effect on inflammatory cytokine plasma levels also use variable participants, including healthy individuals and individuals with various diseases, and variable doses and treatment periods. Additionally, some studies have shown that despite a lack of effect on plasma levels of inflammatory cytokines, resveratrol still suppresses general inflammatory responses [58,70]. Therefore, it may be that in some of the previously mentioned studies showing a lack 
of anti-inflammatory effects of resveratrol, anti-inflammatory effects were simply missed due to the use of plasma cytokines as the only marker of anti-inflammation. Nevertheless, when the clinical evidence is taken together, the effects of resveratrol on inflammation seem to be highly variable and inconclusive. It is hard to know for certain why inconsistent and contradictory effects are observed on general inflammatory effects and even on the same inflammatory biomarker, but it has been proposed by Morton et al. that the variability may be due to the vast inconsistencies in doses used and differences in study populations [87]. In addition, recent studies showing the prominent inter-individual differences in resveratrol metabolism by the human microbiota may account for variability seen in the compound's effects [96]. As the field evolves and new trials are initiated, resveratrol RCTs should focus on using a standardized range of doses so that results can be more easily compared and pre-screening the gut microbiota of participants prior to a trial may be helpful in revealing if the variations seen in resveratrol metabolism result in significant variations in its physiological effects (Table 1; Figure 2).

\subsection{Endothelial Effects}

The endothelium plays an essential and dynamic role in the cardiovascular system. The endothelial cells not only control blood flow and release NO as the primary mediator of proper vascular function but also prevent aggregation of blood cells, and control permeability of substances in the plasma [97]. The endothelium also reduces inflammation through the production of natural anticoagulants [97]. With regard to atherosclerosis, endothelial dysfunction is an essential factor in its pathogenesis [98]. Therefore, a dysfunctional endothelium is associated with high blood pressure [97], inflammation [99], CAD [98], and eventual HF [97,99]. Studies performed in vitro on human cells or animal models have shown that resveratrol has positive effects on endothelium function, including an up regulation of endothelial nitric oxide synthase (eNOS) [100], which is the primary enzyme that produces $\mathrm{NO}$ for the vascular system, and a decrease in the uncoupling of eNOS to reduced oxidative stress [100]. These results, as well as many others, have led to numerous resveratrol RCTs, hoping to see mimicked preclinical endothelial effects of resveratrol supplementation on human endothelial function. Compared to the previously discussed inflammatory effects, RCT results measuring changes in endothelial function, often using flow mediated dilation (FMD) as an indicator, have been less variable. Various studies where resveratrol was administered to diseased participants show an improvement in endothelial function. These improvements were observed in participants with a previous myocardial infarction [95] and participants with metabolic syndromes [44]. A decrease in arterial stiffness (measured by Cardio Ankle Vascular Index) was also observed in participants with type 2 diabetes after resveratrol supplementation [45]. Interestingly, this study also suggests that the positive effects of resveratrol on endothelial function are more pronounced for those who likely had poor endothelial function before the trial began [45]. This is supported by a study performed on obese subjects, which showed that those with worse FMDs before resveratrol supplementation saw a more significant increase in FMD than those with a more normal initial FMD [47]. This effect is further supported by a study on hypertensive participants given resveratrol, which showed that FMD improvement was higher for participants that initially had higher low-density lipoproteins (LDL) levels than in participants that had low initial LDL levels [46]. Moreover, it should be mentioned that endothelial improvement was only observed in the female participants within this study, suggesting potential sex-related differences in resveratrol effects. Due to studies showing a sex-related differences in resveratrol metabolism by the gut microbiome [101], these metabolic differences may be a potential explanation for the results reported. However, further experimentation must be performed in order to determine if this explanation is valid. Nevertheless, in reviewing the recent RCTs involving endothelial function, there is strong evidence that resveratrol supplementation does improve endothelial function. Although the mechanism(s) by which resveratrol improves endothelial function is (are) not entirely known, it has been described by Fujitaka et al. [44] — due to the fact that SIRT1 is known to activate NO synthase and increase endothelial function, resveratrol could improve endothelial function by activating SIRT1 [102]. Like previously stated, this was 
a proposed mechanism for anti-inflammatory effects as well [44]. However, a RCT performed by Gliemann et al. showed that resveratrol supplementation actually blunted the increase of eNOS levels following exercise and did not activate SIRT1 [48]. In addition, several other RCTs have shown a lack of effect of resveratrol on SIRT1 activity [52,55,71]. Consequently, further directions for RCTs investigating the endothelial effects of resveratrol should have a secondary objective of measuring effects on SIRT1 activity following supplementation to see if this mechanism is valid. Generally speaking, since improved endothelial changes due to resveratrol are well documented and a molecular mechanism is not entirely known, future RCTs should also focus on identifying potential mechanisms responsible for endothelial improvement (Table 1; Figure 2).

\subsection{Lipoprotein and Cholesterol Effects}

Disorders of cholesterol and lipoprotein metabolism are a well-known risk factor for atherosclerosis and consequently, a risk factor for CAD and HF as well [103]. In regard to the pathogenesis of atherosclerosis, conditions such as hypercholesterolemia are considered to play a large role [103]. To elaborate, LDL exposed to the macrophages of an atherosclerotic lesion get oxidized, this oxidized LDL (LDL-ox) is then able to injure endothelial cells, aiding in the progression of atherosclerotic lesions [103]. In addition, lipoprotein retention within lesions, which is increased with the presence of LDL, contributes to the formation of severe plaque build-up that may cause acute thrombotic vascular events such as myocardial infarction [103]. Moreover, hypertriglyceridemia is also associated with an increased risk of CVD $[104,105]$. Given the benefits of statin therapy in preventing human CVD [106,107] and the aforementioned role of high plasma LDL, triglycerides, and total cholesterol in the pathogenesis of CAD and eventual HF, statin-therapy-like effects such as a lowering of LDL, triglyceride, and total cholesterol plasma levels are often used as an indicator of cardio-protective effects in RCTs evaluating the cardiovascular effects of a drug, including in trials testing the effects of resveratrol. Likewise, since elevated high density lipoprotein plasma levels relative to LDL levels are inversely related with CAD [108], higher high-density lipoproteins (HDL) levels are often used as indicators of cardio-protective effects of resveratrol as well. In RCTs investigating the effects of resveratrol supplementation on changes in lipid profile, results appear to vary. However, multiple potential mechanisms for how resveratrol could improve the lipid profile in humans have been proposed. These include a decrease in mRNA expression of hepatic 3-hydroxy-3-methyl-glutaryl-CoA (HMG-CoA) reductase [49] (an enzyme involved in cholesterol biogenesis [109]), and an activation of SIRT1 [49], which may potentially lead to reverse cholesterol transport [110] and an amelioration in lipid profile [111].

Despite the ability of resveratrol to mediate these potential pathways, there is more clinical evidence suggesting no direct effect of resveratrol on plasma levels of LDL, HDL, triglycerides, and total cholesterol than evidence suggesting a significant effect. For example, multiple RCTs have shown no effect of resveratrol supplementation at various doses on lipid profile $[44,45,51,52,56,62,68]$. Also, numerous RCTs have reported no effect on specific aspects of the lipid profile such as on LDL cholesterol (LDL-C) [59,61], HDL cholesterol (HDL-C) [61], and triglycerides [54]. Although some RCTs have shown a decrease in plasma levels of total cholesterol [59-61,64], LDL-C [60,95], and triglycerides $[50,64,66,69]$ (note that in the study performed by Militaru et al. resveratrol performed worse than calcium fructoborate at improving triglyceride levels), a meta-analysis conducted by Sahebkar et al., which included many of the previously mentioned studies, found no significant effects of resveratrol on plasma levels of LDL-C, total cholesterol, and triglycerides [67]. Interestingly, this meta-analysis on resveratrol RCTs actually found the overall effect of a decrease in HDL-C plasma concentrations [67]. A more recent meta-analysis performed by Haghighhatdoost et al. found similar results, with no effect of resveratrol on plasma LDL-C levels or HDL-C levels observed [49]. In addition, total cholesterol plasma levels were only lowered in participants with a healthy body mass index (BMI) (not in overweight and obese participants) and triglyceride levels were found to increase following resveratrol supplementation [49]. However, it should be noted 
that when the study done by Zortea et al. [50] was removed from this meta-analysis, the triglyceride increase became insignificant [49]. Moreover, some RCTs investigating resveratrol's effects on lipid profile have shown negative effects such as a blunted decrease in total cholesterol and LDL-C plasma levels following exercise [48], and an increase in total cholesterol and triglyceride plasma levels [65]. Keeping all evidence in mind, especially the meta-analyses, it seems that resveratrol has a lack of effect, or even a detrimental effect, on plasma lipid profile (if the indicator of lipid profile status used is plasma levels of total cholesterol, LDL-C, HDL-C, and triglycerides).

In contrast to the aforementioned studies, a study conducted by Tomé-Carneiro et al. on participants undergoing primary prevention of CVD, showed that resveratrol supplementation resulted in a decrease in both LDL-ox and apolipoprotein B-100 (ApoB) plasma levels (it should be noted that supplement given in this trial was not pure resveratrol and contained various other minor stilbenes) [53]. This is interesting since the study also saw little effect of resveratrol on plasma levels of LDL-C, similar to the previous clinical trials that are often used as evidence of the inefficacy of resveratrol in altering risk of atherosclerosis due to lipoproteins. However, it is argued that decreases in plasma LDL-ox and ApoB are actually more valid indicators of CVD risk reduction than a decrease in LDL-C plasma levels [112]. Therefore, this study shows that despite previous studies showing no reduction in LDL-C levels nor other changes in lipid profile following resveratrol supplementation, the compound may still reduce the risk of atherosclerosis and other CVDs related to lipoproteins via a reduction in small LDL particles (LDL-P) and consequently decreased LDL-ox as well [53]. However, further research is needed to verify these results, since another RCT by Poulsen et al. found resveratrol supplementation to have no effect on lipid oxidation [52]. Overall, the evidence on the effects of resveratrol on lipids are variable and often contradictory. Thus, further research focusing on not just lipid profile, but LDL-ox and LDL-Ps is needed to fully understand if the compound can reduce the risk of CVDs associated with poor cholesterol and lipoprotein metabolism (Table 1; Figure 2).

\subsection{Effects on Hypertension}

Hypertension is not unrelated to the previously discussed pathogenesis of atherosclerosis and CAD. In fact, hypertension is a known contributor to the development of both of these CVDs [113] and effects more than $25 \%$ of the population in developed nations [114]. Furthermore, hypertension leads to damaged myocytes, left ventricular hypertrophy (LVH), and impaired coronary reserve myocardial perfusion, all conditions known to cause HF [113]. Although multiple anti-hypertensive pharmacotherapies that decrease CVD related mortality exist [113], it has been argued that these existing therapies do not always adequately protect against resistant hypertension [115] and end-organ damage. Thus, compounds like resveratrol, which show anti-hypertensive properties in multiple animal model studies [116-118] and that also provide potential multiple end-organ protection [119-122] are a compelling potential treatment or co-treatment for hypertension [115] and have prompted many RCTs to investigate the clinical effects of resveratrol on blood pressure (BP). The proposed mechanisms by which resveratrol could decrease BP, mostly based on preclinical experiments, include the increase in endothelial NO production [33], reductions in vascular inflammation and oxidative damage by an increased expression of SIRT1 in the endothelial cells [33], and decreased $\mathrm{Ca}^{2+}$ influx [33]. However, the clinical evidence of the effects of resveratrol on BP is inconclusive. Studies that show a reduction in BP usually only find a reduction in systolic blood pressure (SBP) and not diastolic blood pressure (DBP) $[44,48,67,89]$. However, this may not be a limitation, since it has been suggested that SBP is more of a risk factor for CVDs than DBP [33]. Moreover, as mentioned by Beshay et al., a few of the studies done on participants with metabolic disorders that show a reduction in SBP $[44,48,89]$ might have been due to metabolic improvements and thus, a direct vasodilating effect of resveratrol cannot be confirmed. In addition, a study conducted by Theodotou et al. on hypertensive participants showed that resveratrol can be used in addition to angiotensin-converting-enzyme (ACE) inhibitors to adequately control BP without the need of another anti-hypertensive medication [123]. 
In contrast to the studies showing a resveratrol-induced SBP and DBP or just SBP reduction, other RCTs conducted on a variety of participants (including studies performed on participants with metabolic diseases) have showed no reduction in SBP [61,71,96,97,103], mean arterial BP [65,97], or peripheral BP [103]. Additionally, meta-analyses have indicated no effect of resveratrol supplementation on SBP or DBP as well $[124,125]$. Interestingly, three meta-analyses investigating the anti-hypertensive effects of resveratrol have all shown a dose dependent effect of the compound on SBP $[67,125]$. In these analyses, resveratrol doses higher than or exactly $300 \mathrm{mg} / \mathrm{d}$ [124], higher than or exactly $300 \mathrm{mg} / \mathrm{d}$ [67], and higher than or exactly $150 \mathrm{mg} / \mathrm{d}$ [125] respectively, resulted in a more pronounced SBP reduction. This is a good indication that higher doses of resveratrol should be used in future RCTs dealing with the BP effects of resveratrol. However, it should be noted that increases in BP have been seen following resveratrol supplementation, including an increase in DBP and heart rate [97] and a blunting of reductions in mean arterial BP following exercise [48].

To explain the lack of effect of resveratrol on BP seen in many studies, it has been suggested that the compound likely exerts more profound effects on a hypertensive population [33]. However, since that suggestion, a RCT conducted on participants with hypertension who received $300 \mathrm{mg} / \mathrm{d}$ of resveratrol has shown no effect on BP [103]. Therefore, the clinical evidence remains inconclusive and contradicting, without a clear explanation for the variability. However, since there is strong evidence showing a resveratrol dose dependent positive relationship with SBP reductions, further RCTs focusing on the effects of resveratrol on BP should use doses at least over $300 \mathrm{mg} / \mathrm{d}$ to properly evaluate this dependency and possibly confirm the reductive effect of resveratrol on SBP at high doses (Table 2; Figure 2). 
Table 2. Summary of Studies Involving Hypertension.

\begin{tabular}{|c|c|c|c|c|c|c|}
\hline Study Done by & Study Design & Subjects & Dose and Treatment Period & Area of Interest & Primary or Key Exploratory Outcomes & Secondary Outcomes \\
\hline \multicolumn{7}{|c|}{ Hypertension } \\
\hline Fogacci et al., 2018 [124] & Meta-analysis & 681 adults & $\begin{array}{l}\text { Several doses for a time period } \\
\text { ranging from } 30 \text { days to } \\
\text { six months }\end{array}$ & $\begin{array}{l}\text { Effects of resveratrol on SBP and DBP } \\
\text { and mean arterial pressure }\end{array}$ & $\begin{array}{l}\text { No significant effect on SBP and DBP or } \\
\text { mean arterial pressure. }\end{array}$ & $\begin{array}{l}\text { Lower DBP in higher } \\
\text { doses (more or exactly } \\
300 \mathrm{mg} / \text { day) and } \\
\text { with diabetic patients. }\end{array}$ \\
\hline Liu et al., 2015 [125] & Meta-analysis & 274 adults & $\begin{array}{c}\text { Doses ranging from } 16 \mathrm{mg} \\
\text { daily to } 1000 \mathrm{mg} \text { daily with } \\
\text { supplementation periods } \\
\text { ranging from } 30 \text { days to } \\
12 \mathrm{months}\end{array}$ & Effect of resveratrol on SBP and DBP & No significant reduction of SBP or DBP. & $\begin{array}{c}\text { Resveratrol was more } \\
\text { effective at reducing } \\
\text { SBP in higher doses } \\
\text { ( } \geq 150 \mathrm{mg} \text { daily). }\end{array}$ \\
\hline Theodotou et al., 2016 [123] & $\begin{array}{c}\text { Double blind, } \\
\text { randomized, } \\
\text { placebo-controlled }\end{array}$ & 97 patients with hypertension & $\begin{array}{l}50 \mathrm{mg} \text { of resveratrol (Elevlor) } \\
\text { daily for six months }\end{array}$ & 97 patients with hypertension & $\begin{array}{l}\text { Resveratrol supplementation with } \\
\text { Dapril reduces BP to normal levels. }\end{array}$ & $\begin{array}{l}\text { Resveratrol prevents } \\
\text { liver damage. }\end{array}$ \\
\hline
\end{tabular}




\subsection{Effects on Diabetes}

Diabetes is one of the major comorbidities associated with HF [126] and is present in as many as $40 \%$ of patients with HF [126-128]. Worsening diabetes is known to cause HF independent of CAD and hypertension with overall 2 to 4 times higher rate in diabetes patients compared to non-diabetic patients, according to the Framingham Heart Study [127,129]. Diabetes may precede the development of cardiac dysfunction and HF, albeit there is also evidence that suggests HF can contribute to the development of insulin resistance and diabetes with a higher rate of incidence with increasing severity of HF [130]. The concomitant presence of diabetes and HF leads to poor prognosis and worse quality of life, hospitalization, increased readmission rate and mortality in the affected population [131]. In addition, the presence of diabetes increases the risk of myocardial infarction (MI) and stroke in HF patients [132]. The abnormalities in glycemic regulation due to insulin deficiency and resistance may directly perturb cardiac function by altering the normal myocardial energetics and contribute to HF in the absence of CAD and hypertension [133]. Other underlying diabetes-induced pathophysiological factors that cumulatively affect the myocardium include advanced glycation products, lipotoxicity, impaired calcium handling, oxidative stress, mitochondrial dysfunction, and inflammation [133]. Currently, there is a lack of clear consensus in accurately defining the term diabetic cardiomyopathy and its pathophysiology [134]. However, evidence from pre-clinical and clinical characteristics point to the role of progressive diastolic dysfunction and late systolic dysfunction in the culmination of HF [134]. In conjunction with HF medical therapy, diabetes management is also increasingly recognized as an important issue to tackle when both HF and diabetes coexist [134-136]. The current standard of care does not differ for HF patients with and without diabetes [134]. That being said, the advent of novel compelling information on the efficacy of new diabetic drugs such as sodium-glucose cotransporter (SGLT) 2 inhibitors in HF management may offer new opportunity for improving the prognosis and outcomes in HF patients with and without diabetes $[137,138]$. Interestingly, resveratrol improves insulin sensitivity and glucose metabolism in rodent and non-human primates in the setting of type 1 and type 2 diabetes, metabolic syndrome, and aging [139-141]. Resveratrol mediated anti-diabetic effects have been attributed to the decrease in hepatic glucose production, activation of AMPK, a master regulator of metabolism, improved glucose uptake via an increase in glucose transporter, and reduction in oxidative stress [142]. In addition, resveratrol has been shown to improve cardiac structure and function in the setting of type 1 and type 2 diabetes $[143,144]$. Consistent with the pre-clinical studies that reported the anti-diabetic properties of resveratrol, a few clinical trials have also reported the protective effects of resveratrol against diabetic complications such as insulin resistance, hyperinsulinemia and hyperglycemia [69,142,145-148]. Moreover, a meta-analysis of 11 studies reported that short-term consumption of resveratrol reduces fasting glucose, insulin, glycated hemoglobin, and insulin resistance in diabetes patients [149] (Tables 1 and 2; Figure 2).

\subsection{Effects on Heart Failure and Left Ventricle Function}

Since it is likely that resveratrol may have beneficial effects in numerous CVDs that can contribute to $\mathrm{HF}$ and/or are comorbidities of HF, it stands to reason that resveratrol may hold promise for the treatment of clinical HF. Interestingly, numerous animal models of ischemic and non-ischemic HF have shown beneficial effects of resveratrol in HF that either prolongs survival [38], improves diastolic [38] or systolic function [150], reduces negative atrial and left ventricular remodeling [38,151,152], improves hemodynamics and cardiac energetics [153] and/or improves exercise capacity [154]. However, despite these preclinical studies, it is still unknown if resveratrol can improve HF in humans. That said, in a double-blind, placebo-controlled trial involving patients with stable coronary artery disease receiving $10 \mathrm{mg}$ of resveratrol/day for 3 months, resveratrol improved left ventricle diastolic function [95]. Moreover, $20 \mathrm{mg}$ of resveratrol/day administered for 60 days resulted in a significant decrease in b-type natriuretic peptide (BNP) in patients with angina pectoris, suggesting improved left ventricle function [64]. Although limited, these studies suggest that resveratrol may have a direct impact on myocardial function in humans. While this does not demonstrate that resveratrol will 
improve myocardial performance in patients with $\mathrm{HF}$, it does provide interesting data that suggests that clinical trials in the area are warranted.

Due to the interest in the area, clinical trials have been initiated involving patients with HF. The REV-HF (Evaluating the Clinical Efficacy of REsVeratrol in Improving Metabolic and Skeletal Muscle Function in Patients with Heart Failure clinicaltrials.govNCT03525379) is a randomized, double-blind, placebo-controlled trial evaluating the change in skeletal muscle function $\mathrm{VO}_{2}$ after 8 weeks of therapy in patients with HF. In addition, the RES-HF trial (RESveratrol: a Potential Anti-remodeling Agent in Heart Failure, clinicaltrials.govNCT01914081) is a randomized, double blinded, placebo-controlled study designed to assess the clinical efficacy and safety of one year of resveratrol therapy in ischemic and non-ischemic HF patients. The primary and secondary objectives include changes in echocardiographic and patient reported outcome measures (Minnesota Living with Heart Failure Questionnaire), endothelial function, body fat and lean muscle mass as well as biomarkers of inflammation, antioxidant and NO activity. In addition, RES-HF will also help determine the safety and tolerability of high-dose long-term resveratrol treatment in HF patients and provide compelling new information on the therapeutic potential of resveratrol as an adjunct to current HF medical therapy (Table 3; Figure 2). 
Table 3. Summary of Studies Involving Heart Failure and Left Ventricular Dysfunction.

\begin{tabular}{|c|c|c|c|c|c|c|}
\hline Study Done by & Study Design & Subjects & Dose and Treatment Period & Area of Interest & Primary or Key Exploratory Outcomes & Secondary Outcomes \\
\hline \multicolumn{7}{|c|}{ Heart Failure/LV Function } \\
\hline Maygar et al., 2012 [95] & $\begin{array}{l}\text { Double blind, } \\
\text { randomized, } \\
\text { placebo-controlled }\end{array}$ & $\begin{array}{l}40 \text { adults who had } \\
\text { a previous } \\
\text { myocardial infarction }\end{array}$ & $\begin{array}{l}10 \mathrm{mg} \text { of resveratrol daily for } \\
3 \text { months }\end{array}$ & $\begin{array}{l}\text { Cardio-protective } \\
\text { effects of resveratrol }\end{array}$ & $\begin{array}{l}\text { Improvement in left ventricular diastolic } \\
\text { function, endothelial functioning } \\
\text { (FMD improvements). } \\
\text { Decrease in plasma LDL levels. } \\
\text { No effect on HbA1c, TNF-alpha, or CRP. }\end{array}$ & \\
\hline
\end{tabular}




\section{Conclusions}

Resveratrol presents a therapeutic agent with a novel mechanism of action that appears to benefit a variety of conditions related to CVD and HF. Ongoing studies will test the hypothesis that the addition of resveratrol in meaningful doses can help patients with CVD and/or HF.

Funding: This work was supported by grants from the Canadian Institutes of Health Research and the Alberta Diabetes Institute to JAE and JRBD. JRBD is a Canada Research Chair in Molecular Medicine.

Conflicts of Interest: The authors declare no conflict of interest.

\section{References}

1. Cardiovascular diseases (CVDs)—World Health Organization. Cardiovascular diseases (CVDs).

2. Heart Disease in Canada. Heart disease-Heart health.

3. Stern, C.S.; Lebowitz, J. Latest drug developments in the field of cardiovascular disease. Int. J. Angiol. 2010, 19, e100-e105. [CrossRef] [PubMed]

4. Rao, P.S.; Harris, A.D. Recent advances in managing septal defects: Ventricular septal defects and atrioventricular septal defects. F1000 Res. 2018, 7. [CrossRef] [PubMed]

5. Heart and Stroke Foundation. Foundation., H.a.S. Report on the Health of Canadians.

6. Kannel, W.B.; D'Agostino, R.B.; Silbershatz, H.; Belanger, A.J.; Wilson, P.W.; Levy, D. Profile for estimating risk of heart failure. Arch. Int. Med. 1999, 159, 1197-1204. [CrossRef]

7. Johansen, H.; Strauss, B.; Arnold, J.M.; Moe, G.; Liu, P. On the rise: The current and projected future burden of congestive heart failure hospitalization in Canada. Can. J. Cardiol. 2003, 19, 430-435. [PubMed]

8. Jong, P.; Gong, Y.; Liu, P.P.; Austin, P.C.; Lee, D.S.; Tu, J.V. Care and outcomes of patients newly hospitalized for heart failure in the community treated by cardiologists compared with other specialists. Circulation 2003, 108, 184-191. [CrossRef] [PubMed]

9. Arnold, J.M.; Liu, P.; Demers, C.; Dorian, P.; Giannetti, N.; Haddad, H.; Heckman, G.A.; Howlett, J.G.; Ignaszewski, A.; Johnstone, D.E.; et al. Canadian Cardiovascular Society consensus conference recommendations on heart failure 2006: Diagnosis and management. Can. J. Cardiol. 2006, 22, $23-45$. [CrossRef]

10. Redfield, M.M.; Jacobsen, S.J.; Burnett, J.C., Jr.; Mahoney, D.W.; Bailey, K.R.; Rodeheffer, R.J. Burden of systolic and diastolic ventricular dysfunction in the community: Appreciating the scope of the heart failure epidemic. Jama 2003, 289, 194-202. [CrossRef] [PubMed]

11. Yancy, C.W.; Lopatin, M.; Stevenson, L.W.; De Marco, T.; Fonarow, G.C. Clinical presentation, management, and in-hospital outcomes of patients admitted with acute decompensated heart failure with preserved systolic function: A report from the Acute Decompensated Heart Failure National Registry (ADHERE) Database. J Am. Coll Cardiol. 2006, 47, 76-84. [CrossRef] [PubMed]

12. Cleland, J.G.; Tendera, M.; Adamus, J.; Freemantle, N.; Polonski, L.; Taylor, J. The perindopril in elderly people with chronic heart failure (PEP-CHF) study. Eur. Heart J. 2006, 27, 2338-2345. [CrossRef] [PubMed]

13. Tran, T.T.; Ohinmaa, A.; Thanh, N.X.; Howlett, J.G.; Ezekowitz, J.A.; McAlister, F.A.; Kaul, P. The current and future financial burden of hospital admissions for heart failure in Canada: A cost analysis. Can. Med Assoc. J. 2016, 4, E365-E370. [CrossRef] [PubMed]

14. Raj, P.; Louis, X.L.; Thandapilly, S.J.; Movahed, A.; Zieroth, S.; Netticadan, T. Potential of resveratrol in the treatment of heart failure. Life Sci. 2014, 95, 63-71. [CrossRef] [PubMed]

15. Muller-Werdan, U.; Stockl, G.; Werdan, K. Advances in the management of heart failure: The role of ivabradine. Vasc. Health Risk Manag. 2016, 12, 453-470. [CrossRef] [PubMed]

16. Singh, J.S.; Lang, C.C. Angiotensin receptor-neprilysin inhibitors: Clinical potential in heart failure and beyond. Vasc. Health Risk Manag. 2015, 11, 283-295. [PubMed]

17. Yandrapalli, S.; Khan, M.H.; Rochlani, Y.; Aronow, W.S. Sacubitril/valsartan in cardiovascular disease: Evidence to date and place in therapy. Ther. Adv. Cardiovasc. Dis. 2018, 12, 217-231. [CrossRef] [PubMed]

18. Sung, M.M.; Dyck, J.R. Therapeutic potential of resveratrol in heart failure. Ann. N. Y. Acad. Sci. 2015, 1348, 32-45. [CrossRef] [PubMed]

19. Ayers, J.; Cook, J.; Koenig, R.A.; Sisson, E.M.; Dixon, D.L. Recent Developments in the Role of Coenzyme Q10 for Coronary Heart Disease: A Systematic Review. Curr. Atheroscler. Rep. 2018, 20, 29. [CrossRef] [PubMed] 
20. Pagano, E.; Romano, B.; Izzo, A.A.; Borrelli, F. The clinical efficacy of curcumin-containing nutraceuticals: An overview of systematic reviews. Pharmacol. Res. 2018, 134, 79-91. [CrossRef] [PubMed]

21. Thota, R.N.; Ferguson, J.J.A.; Abbott, K.A.; Dias, C.B.; Garg, M.L. Science behind the cardio-metabolic benefits of omega-3 polyunsaturated fatty acids: Biochemical effects vs. clinical outcomes. Food Funct. 2018, 9, 3576-3596. [CrossRef] [PubMed]

22. Thandapilly, S.J.; Wojciechowski, P.; Behbahani, J.; Louis, X.L.; Yu, L.; Juric, D.; Kopilas, M.A.; Anderson, H.D.; Netticadan, T. Resveratrol prevents the development of pathological cardiac hypertrophy and contractile dysfunction in the SHR without lowering blood pressure. Am. J. Hypertens 2010, 23, 192-196. [CrossRef] [PubMed]

23. Gupta, P.K.; DiPette, D.J.; Supowit, S.C. Protective effect of resveratrol against pressure overload-induced heart failure. Food Sci. Nutr. 2014, 2, 218-229. [CrossRef] [PubMed]

24. Chen, F.; Qian, L.H.; Deng, B.; Liu, Z.M.; Zhao, Y.; Le, Y.Y. Resveratrol protects vascular endothelial cells from high glucose-induced apoptosis through inhibition of NADPH oxidase activation-driven oxidative stress. CNS Neurosci. Ther. 2013, 19, 675-681. [CrossRef] [PubMed]

25. Lin, J.F.; Wu, S.; Huang, S.S.; Lu, B.Y.; Lin, S.M.; Tsai, S.K. Resveratrol protects left ventricle by increasing adenylate kinase and isocitrate dehydrogenase activities in rats with myocardial infarction. Chin. J. Physiol. 2011, 54, 406-412. [PubMed]

26. Szekeres, T.; Fritzer-Szekeres, M.; Saiko, P.; Jager, W. Resveratrol and resveratrol analogues-structure-activity relationship. Pharm. Res. 2010, 27, 1042-1048. [CrossRef] [PubMed]

27. National Center for Biotechnology Information. Resveratrol. PubChem Compound Database; CID=445154. Available online: https:/ / pubchem.ncbi.nlm.nih.gov/compound/445154 (accessed on 6 September 2018).

28. Ahuja, I.; Kissen, R.; Bones, A.M. Phytoalexins in defense against pathogens. Trends Plant Sci. 2012, 17, 73-90. [CrossRef] [PubMed]

29. Dolinsky, V.W.; Dyck, J.R. Calorie restriction and resveratrol in cardiovascular health and disease. Biochim. Biophys. Acta 2011, 1812, 1477-1489. [CrossRef] [PubMed]

30. Block, G.; Jensen, C.D.; Norkus, E.P.; Dalvi, T.B.; Wong, L.G.; McManus, J.F.; Hudes, M.L. Usage patterns, health, and nutritional status of long-term multiple dietary supplement users: A cross-sectional study. Nutr. J. 2007, 6, 30. [CrossRef] [PubMed]

31. Kroon, P.A.; Iyer, A.; Chunduri, P.; Chan, V.; Brown, L. The cardiovascular nutrapharmacology of resveratrol: Pharmacokinetics, molecular mechanisms and therapeutic potential. Curr. Med. Chem. 2010, 17, 2442-2455. [CrossRef]

32. Boocock, D.J.; Faust, G.E.; Patel, K.R.; Schinas, A.M.; Brown, V.A.; Ducharme, M.P.; Booth, T.D.; Crowell, J.A.; Perloff, M.; Gescher, A.J.; et al. Phase I dose escalation pharmacokinetic study in healthy volunteers of resveratrol, a potential cancer chemopreventive agent. Cancer Epidemiol. Biomark. Prev. 2007, 16, 1246-1252. [CrossRef]

33. Zordoky, B.N.; Robertson, I.M.; Dyck, J.R. Preclinical and clinical evidence for the role of resveratrol in the treatment of cardiovascular diseases. Biochim. Biophys. Acta 2015, 1852, 1155-1177. [CrossRef]

34. Xu, D.; Li, Y.; Zhang, B.; Wang, Y.; Liu, Y.; Luo, Y.; Niu, W.; Dong, M.; Liu, M.; Dong, H.; et al. Resveratrol alleviate hypoxic pulmonary hypertension via anti-inflammation and anti-oxidant pathways in rats. Int. J. Med. Sci. 2016, 13, 942-954. [CrossRef]

35. Kundu, J.K.; Shin, Y.K.; Kim, S.H.; Surh, Y.J. Resveratrol inhibits phorbol ester-induced expression of COX-2 and activation of NF-kappaB in mouse skin by blocking IkappaB kinase activity. Carcinogenesis 2006, 27, 1465-1474. [CrossRef] [PubMed]

36. Tasatargil, A.; Tanriover, G.; Barutcigil, A.; Turkmen, E. Protective effect of resveratrol on methylglyoxal-induced endothelial dysfunction in aged rats. Aging Clin. Exp. Res. 2018, 31, 1-8. [CrossRef] [PubMed]

37. Chung, J.H.; Manganiello, V.; Dyck, J.R. Resveratrol as a calorie restriction mimetic: Therapeutic implications. Trends Cell Biol. 2012, 22, 546-554. [CrossRef] [PubMed]

38. Sung, M.M.; Das, S.K.; Levasseur, J.; Byrne, N.J.; Fung, D.; Kim, T.T.; Masson, G.; Boisvenue, J.; Soltys, C.L.; Oudit, G.Y.; et al. Resveratrol treatment of mice with pressure-overload-induced heart failure improves diastolic function and cardiac energy metabolism. Circ. Heart Fail. 2015, 8, 128-137. [CrossRef] [PubMed] 
39. Smoliga, J.M.; Colombo, E.S.; Campen, M.J. A healthier approach to clinical trials evaluating resveratrol for primary prevention of age-related diseases in healthy populations. Aging 2013, 5, 495-506. [CrossRef] [PubMed]

40. Gambini, J.; Ingles, M.; Olaso, G.; Lopez-Grueso, R.; Bonet-Costa, V.; Gimeno-Mallench, L.; Mas-Bargues, C.; Abdelaziz, K.M.; Gomez-Cabrera, M.C.; Vina, J.; et al. Properties of Resveratrol: In Vitro and In Vivo Studies about Metabolism, Bioavailability, and Biological Effects in Animal Models and Humans. Oxidative Med. Cell. Longev. 2015, 2015, 837042. [CrossRef]

41. Libby, P.; Ridker, P.M.; Maseri, A. Inflammation and atherosclerosis. Circulation 2002, 105, $1135-1143$. [CrossRef]

42. Golia, E.; Limongelli, G.; Natale, F.; Fimiani, F.; Maddaloni, V.; Pariggiano, I.; Bianchi, R.; Crisci, M.; D'Acierno, L.; Giordano, R.; et al. Inflammation and cardiovascular disease: From pathogenesis to therapeutic target. Curr. Atheroscler. Rep. 2014, 16, 435. [CrossRef]

43. Lala, A.; Desai, A.S. The role of coronary artery disease in heart failure. Heart Fail. Clin. 2014, 10, 353-365. [CrossRef]

44. Fujitaka, K.; Otani, H.; Jo, F.; Jo, H.; Nomura, E.; Iwasaki, M.; Nishikawa, M.; Iwasaka, T.; Das, D.K. Modified resveratrol Longevinex improves endothelial function in adults with metabolic syndrome receiving standard treatment. Nutr. Res. 2011, 31, 842-847. [CrossRef]

45. Imamura, H.; Yamaguchi, T.; Nagayama, D.; Saiki, A.; Shirai, K.; Tatsuno, I. Resveratrol Ameliorates Arterial Stiffness Assessed by Cardio-Ankle Vascular Index in Patients With Type 2 Diabetes Mellitus. Int. Heart J. 2017, 58, 577-583. [CrossRef] [PubMed]

46. Marques, B.; Trindade, M.; Aquino, J.C.F.; Cunha, A.R.; Gismondi, R.O.; Neves, M.F.; Oigman, W. Beneficial effects of acute trans-resveratrol supplementation in treated hypertensive patients with endothelial dysfunction. Clin. Exp. Hypertens. 2018, 40, 218-223. [CrossRef] [PubMed]

47. Wong, R.H.; Berry, N.M.; Coates, A.M.; Buckley, J.D.; Bryan, J.; Kunz, I.; Howe, P.R. Chronic resveratrol consumption improves brachial flow-mediated dilatation in healthy obese adults. J. Hypertens. 2013, 31, 1819-1827. [CrossRef] [PubMed]

48. Gliemann, L.; Schmidt, J.F.; Olesen, J.; Bienso, R.S.; Peronard, S.L.; Grandjean, S.U.; Mortensen, S.P.; Nyberg, M.; Bangsbo, J.; Pilegaard, H.; et al. Resveratrol blunts the positive effects of exercise training on cardiovascular health in aged men. J. Physiol. 2013, 591, 5047-5059. [CrossRef] [PubMed]

49. Haghighatdoost, F.; Hariri, M. Effect of resveratrol on lipid profile: An updated systematic review and meta-analysis on randomized clinical trials. Pharmacol. Res. 2018, 129, 141-150. [CrossRef] [PubMed]

50. Zortea, K.; Franco, V.C.; Guimaraes, P.; Belmonte-de-Abreu, P.S. Resveratrol Supplementation Did Not Improve Cognition in Patients with Schizophrenia: Results from a Randomized Clinical Trial. Front. Psychiatry 2016, 7, 159. [CrossRef]

51. Heeboll, S.; Kreuzfeldt, M.; Hamilton-Dutoit, S.; Kjaer Poulsen, M.; Stodkilde-Jorgensen, H.; Moller, H.J.; Jessen, N.; Thorsen, K.; Kristina Hellberg, Y.; Bonlokke Pedersen, S.; et al. Placebo-controlled, randomised clinical trial: High-dose resveratrol treatment for non-alcoholic fatty liver disease. Scand. J. Gastroenterol. 2016, 51, 456-464. [CrossRef]

52. Poulsen, M.M.; Vestergaard, P.F.; Clasen, B.F.; Radko, Y.; Christensen, L.P.; Stodkilde-Jorgensen, H.; Moller, N.; Jessen, N.; Pedersen, S.B.; Jorgensen, J.O. High-dose resveratrol supplementation in obese men: An investigator-initiated, randomized, placebo-controlled clinical trial of substrate metabolism, insulin sensitivity, and body composition. Diabetes 2013, 62, 1186-1195. [CrossRef]

53. Tome-Carneiro, J.; Gonzalvez, M.; Larrosa, M.; Garcia-Almagro, F.J.; Aviles-Plaza, F.; Parra, S.; Yanez-Gascon, M.J.; Ruiz-Ros, J.A.; Garcia-Conesa, M.T.; Tomas-Barberan, F.A.; et al. Consumption of a grape extract supplement containing resveratrol decreases oxidized LDL and ApoB in patients undergoing primary prevention of cardiovascular disease: A triple-blind, 6-month follow-up, placebo-controlled, randomized trial. Mol. Nutr. Food Res. 2012, 56, 810-821. [CrossRef]

54. Zare Javid, A.; Hormoznejad, R.; Yousefimanesh, H.A.; Zakerkish, M.; Haghighi-Zadeh, M.H.; Dehghan, P.; Ravanbakhsh, M. The Impact of Resveratrol Supplementation on Blood Glucose, Insulin, Insulin Resistance, Triglyceride, and Periodontal Markers in Type 2 Diabetic Patients with Chronic Periodontitis. Phytother. Res. 2017, 31, 108-114. [CrossRef] 
55. Olesen, J.; Gliemann, L.; Bienso, R.; Schmidt, J.; Hellsten, Y.; Pilegaard, H. Exercise training, but not resveratrol, improves metabolic and inflammatory status in skeletal muscle of aged men. J. Physiol. 2014, 592, 1873-1886. [CrossRef] [PubMed]

56. Tome-Carneiro, J.; Gonzalvez, M.; Larrosa, M.; Yanez-Gascon, M.J.; Garcia-Almagro, F.J.; Ruiz-Ros, J.A.; Tomas-Barberan, F.A.; Garcia-Conesa, M.T.; Espin, J.C. Grape resveratrol increases serum adiponectin and downregulates inflammatory genes in peripheral blood mononuclear cells: A triple-blind, placebo-controlled, one-year clinical trial in patients with stable coronary artery disease. Cardiovasc. Drugs Ther. 2013, 27, 37-48. [CrossRef] [PubMed]

57. Tome-Carneiro, J.; Gonzalvez, M.; Larrosa, M.; Yanez-Gascon, M.J.; Garcia-Almagro, F.J.; Ruiz-Ros, J.A.; Garcia-Conesa, M.T.; Tomas-Barberan, F.A.; Espin, J.C. One-year consumption of a grape nutraceutical containing resveratrol improves the inflammatory and fibrinolytic status of patients in primary prevention of cardiovascular disease. Am. J. Cardiol. 2012, 110, 356-363. [CrossRef] [PubMed]

58. Agarwal, B.; Campen, M.J.; Channell, M.M.; Wherry, S.J.; Varamini, B.; Davis, J.G.; Baur, J.A.; Smoliga, J.M. Resveratrol for primary prevention of atherosclerosis: Clinical trial evidence for improved gene expression in vascular endothelium. Int. J. Cardiol. 2013, 166, 246-248. [CrossRef]

59. Bhatt, J.K.; Thomas, S.; Nanjan, M.J. Resveratrol supplementation improves glycemic control in type 2 diabetes mellitus. Nutr. Res. 2012, 32, 537-541. [CrossRef]

60. Chen, S.; Zhao, X.; Ran, L.; Wan, J.; Wang, X.; Qin, Y.; Shu, F.; Gao, Y.; Yuan, L.; Zhang, Q.; et al. Resveratrol improves insulin resistance, glucose and lipid metabolism in patients with non-alcoholic fatty liver disease: A randomized controlled trial. Dig. Liver Dis. 2015, 47, 226-232. [CrossRef]

61. Huang, H.; Chen, G.; Liao, D.; Zhu, Y.; Pu, R.; Xue, X. The effects of resveratrol intervention on risk markers of cardiovascular health in overweight and obese subjects: A pooled analysis of randomized controlled trials. Obes. Rev. 2016, 17, 1329-1340. [CrossRef]

62. Macedo, R.C.; Vieira, A.; Marin, D.P.; Otton, R. Effects of chronic resveratrol supplementation in military firefighters undergo a physical fitness test-a placebo-controlled, double blind study. Chem. -Biol. Interact. 2015, 227, 89-95. [CrossRef]

63. Mendez-del Villar, M.; Gonzalez-Ortiz, M.; Martinez-Abundis, E.; Perez-Rubio, K.G.; Lizarraga-Valdez, R. Effect of resveratrol administration on metabolic syndrome, insulin sensitivity, and insulin secretion. Metab. Syndr. Related Disord. 2014, 12, 497-501. [CrossRef]

64. Militaru, C.; Donoiu, I.; Craciun, A.; Scorei, I.D.; Bulearca, A.M.; Scorei, R.I. Oral resveratrol and calcium fructoborate supplementation in subjects with stable angina pectoris: Effects on lipid profiles, inflammation markers, and quality of life. Nutrition 2013, 29, 178-183. [CrossRef]

65. Bo, S.; Ponzo, V.; Ciccone, G.; Evangelista, A.; Saba, F.; Goitre, I.; Procopio, M.; Pagano, G.F.; Cassader, M.; Gambino, R. Six months of resveratrol supplementation has no measurable effect in type 2 diabetic patients. A randomized, double blind, placebo-controlled trial. Pharmacol. Res. 2016, 111, 896-905. [CrossRef]

66. Bo, S.; Ciccone, G.; Castiglione, A.; Gambino, R.; De Michieli, F.; Villois, P.; Durazzo, M.; Cavallo-Perin, P.; Cassader, M. Anti-inflammatory and antioxidant effects of resveratrol in healthy smokers a randomized, double-blind, placebo-controlled, cross-over trial. Curr. Med. Chem. 2013, 20, 1323-1331. [CrossRef] [PubMed]

67. Sahebkar, A. Effects of resveratrol supplementation on plasma lipids: A systematic review and meta-analysis of randomized controlled trials. Nutr. Rev. 2013, 71, 822-835. [CrossRef] [PubMed]

68. van der Made, S.M.; Plat, J.; Mensink, R.P. Resveratrol does not influence metabolic risk markers related to cardiovascular health in overweight and slightly obese subjects: A randomized, placebo-controlled crossover trial. PLoS ONE 2015, 10, e0118393. [CrossRef] [PubMed]

69. Timmers, S.; Konings, E.; Bilet, L.; Houtkooper, R.H.; van de Weijer, T.; Goossens, G.H.; Hoeks, J.; van der Krieken, S.; Ryu, D.; Kersten, S.; et al. Calorie Restriction-like Effects of 30 Days of Resveratrol Supplementation on Energy Metabolism and Metabolic Profile in Obese Humans. Cell Metab. 2011, 14, 612-622. [CrossRef]

70. Tome-Carneiro, J.; Larrosa, M.; Yanez-Gascon, M.J.; Davalos, A.; Gil-Zamorano, J.; Gonzalvez, M.; Garcia-Almagro, F.J.; Ruiz Ros, J.A.; Tomas-Barberan, F.A.; Espin, J.C.; et al. One-year supplementation with a grape extract containing resveratrol modulates inflammatory-related microRNAs and cytokines expression in peripheral blood mononuclear cells of type 2 diabetes and hypertensive patients with coronary artery disease. Pharmacol. Res. 2013, 72, 69-82. [CrossRef] 
71. Yoshino, J.; Conte, C.; Fontana, L.; Mittendorfer, B.; Imai, S.; Schechtman, K.B.; Gu, C.; Kunz, I.; Rossi Fanelli, F.; Patterson, B.W.; et al. Resveratrol supplementation does not improve metabolic function in nonobese women with normal glucose tolerance. Cell Metab. 2012, 16, 658-664. [CrossRef]

72. Siti, H.N.; Kamisah, Y.; Kamsiah, J. The role of oxidative stress, antioxidants and vascular inflammation in cardiovascular disease (a review). Vasc. Pharmacol. 2015, 71, 40-56. [CrossRef]

73. Topper, J.N.; Cai, J.; Falb, D.; Gimbrone, M.A., Jr. Identification of vascular endothelial genes differentially responsive to fluid mechanical stimuli: Cyclooxygenase-2, manganese superoxide dismutase, and endothelial cell nitric oxide synthase are selectively up-regulated by steady laminar shear stress. Proc. Natl. Acad. Sci. USA 1996, 93, 10417-10422. [CrossRef]

74. Lee, R.T.; Yamamoto, C.; Feng, Y.; Potter-Perigo, S.; Briggs, W.H.; Landschulz, K.T.; Turi, T.G.; Thompson, J.F.; Libby, P.; Wight, T.N. Mechanical strain induces specific changes in the synthesis and organization of proteoglycans by vascular smooth muscle cells. J. Biol. Chem. 2001, 276, 13847-13851. [CrossRef]

75. Mach, F.; Sauty, A.; Iarossi, A.S.; Sukhova, G.K.; Neote, K.; Libby, P.; Luster, A.D. Differential expression of three T lymphocyte-activating CXC chemokines by human atheroma-associated cells. J. Clin. Investig. 1999, 104, 1041-1050. [CrossRef]

76. Gu, L.; Okada, Y.; Clinton, S.K.; Gerard, C.; Sukhova, G.K.; Libby, P.; Rollins, B.J. Absence of monocyte chemoattractant protein-1 reduces atherosclerosis in low density lipoprotein receptor-deficient mice. Mol. Cell 1998, 2, 275-281. [CrossRef]

77. Smith, J.D.; Trogan, E.; Ginsberg, M.; Grigaux, C.; Tian, J.; Miyata, M. Decreased atherosclerosis in mice deficient in both macrophage colony-stimulating factor (op) and apolipoprotein E. Proc. Natl. Acad. Sci. USA 1995, 92, 8264-8268. [CrossRef]

78. Hansson, G.K.; Libby, P. The role of the lymphocyte. In Atherosclerosis and Coronary Artery Disease; Fuster, V., Ross, R., Topol, E.J., Eds.; Lippincott-Raven: Philadelphia, PA, USA, 1996; Volume 1, pp. 557-568.

79. Ross, R. Atherosclerosis-An inflammatory disease. New Engl. J. Med. 1999, 340, 115-126. [CrossRef]

80. Bartekova, M.; Radosinska, J.; Jelemensky, M.; Dhalla, N.S. Role of cytokines and inflammation in heart function during health and disease. Heart Fail. Rev. 2018, 23, 733-758. [CrossRef]

81. Candelario-Jalil, E.; de Oliveira, A.C.; Graf, S.; Bhatia, H.S.; Hull, M.; Munoz, E.; Fiebich, B.L. Resveratrol potently reduces prostaglandin E2 production and free radical formation in lipopolysaccharide-activated primary rat microglia. J. Neuroinflamm. 2007, 4, 25. [CrossRef] [PubMed]

82. Manna, S.K.; Mukhopadhyay, A.; Aggarwal, B.B. Resveratrol suppresses TNF-induced activation of nuclear transcription factors NF-kappa B, activator protein-1, and apoptosis: Potential role of reactive oxygen intermediates and lipid peroxidation. J. Immunol. 2000, 164, 6509-6519. [CrossRef] [PubMed]

83. Tsai, S.H.; Lin-Shiau, S.Y.; Lin, J.K. Suppression of nitric oxide synthase and the down-regulation of the activation of NFkappaB in macrophages by resveratrol. Br. J. Pharmacol. 1999, 126, 673-680. [CrossRef] [PubMed]

84. Knobloch, J.; Wahl, C.; Feldmann, M.; Jungck, D.; Strauch, J.; Stoelben, E.; Koch, A. Resveratrol attenuates the release of inflammatory cytokines from human bronchial smooth muscle cells exposed to lipoteichoic acid in chronic obstructive pulmonary disease. Basic Clin. Pharmacol. Toxicol. 2014, 114, 202-209. [CrossRef]

85. Csiszar, A.; Smith, K.; Labinskyy, N.; Orosz, Z.; Rivera, A.; Ungvari, Z. Resveratrol attenuates TNF-alpha-induced activation of coronary arterial endothelial cells: Role of NF-kappaB inhibition. Am. J. Physiol. 2006, 291, H1694-H1699.

86. Wang, B.; Sun, J.; Li, X.; Zhou, Q.; Bai, J.; Shi, Y.; Le, G. Resveratrol prevents suppression of regulatory T-cell production, oxidative stress, and inflammation of mice prone or resistant to high-fat diet-induced obesity. Nutr. Res. 2013, 33, 971-981. [CrossRef]

87. Poulsen, M.M.; Fjeldborg, K.; Ornstrup, M.J.; Kjaer, T.N.; Nohr, M.K.; Pedersen, S.B. Resveratrol and inflammation: Challenges in translating pre-clinical findings to improved patient outcomes. Biochim. Biophys. Acta 2015, 1852, 1124-1136. [CrossRef] [PubMed]

88. Planavila, A.; Iglesias, R.; Giralt, M.; Villarroya, F. Sirt1 acts in association with PPARalpha to protect the heart from hypertrophy, metabolic dysregulation, and inflammation. Cardiovasc. Res. 2011, 90, 276-284. [CrossRef] [PubMed]

89. Yoshizaki, T.; Milne, J.C.; Imamura, T.; Schenk, S.; Sonoda, N.; Babendure, J.L.; Lu, J.C.; Smith, J.J.; Jirousek, M.R.; Olefsky, J.M. SIRT1 exerts anti-inflammatory effects and improves insulin sensitivity in adipocytes. Mol. Cell. Biol. 2009, 29, 1363-1374. [CrossRef] [PubMed] 
90. Rieder, S.A.; Nagarkatti, P.; Nagarkatti, M. Multiple anti-inflammatory pathways triggered by resveratrol lead to amelioration of staphylococcal enterotoxin B-induced lung injury. Br. J. Pharmacol. 2012, 167, 1244-1258. [CrossRef] [PubMed]

91. Cao, D.; Wang, M.; Qiu, X.; Liu, D.; Jiang, H.; Yang, N.; Xu, R.M. Structural basis for allosteric, substrate-dependent stimulation of SIRT1 activity by resveratrol. Genes Dev. 2015, 29, 1316-1325. [CrossRef] [PubMed]

92. Howitz, K.T.; Bitterman, K.J.; Cohen, H.Y.; Lamming, D.W.; Lavu, S.; Wood, J.G.; Zipkin, R.E.; Chung, P.; Kisielewski, A.; Zhang, L.L.; et al. Small molecule activators of sirtuins extend Saccharomyces cerevisiae lifespan. Nature 2003, 425, 191-196. [CrossRef] [PubMed]

93. Ghanim, H.; Sia, C.L.; Abuaysheh, S.; Korzeniewski, K.; Patnaik, P.; Marumganti, A.; Chaudhuri, A.; Dandona, P. An antiinflammatory and reactive oxygen species suppressive effects of an extract of Polygonum cuspidatum containing resveratrol. J. Clin. Endocrinol. Metab. 2010, 95, E1-E8. [CrossRef] [PubMed]

94. Bakker, G.C.; van Erk, M.J.; Pellis, L.; Wopereis, S.; Rubingh, C.M.; Cnubben, N.H.; Kooistra, T.; van Ommen, B.; Hendriks, H.F. An antiinflammatory dietary mix modulates inflammation and oxidative and metabolic stress in overweight men: A nutrigenomics approach. Am. J. Clin. Nutr. 2010, 91, 1044-1059. [CrossRef] [PubMed]

95. Magyar, K.; Halmosi, R.; Palfi, A.; Feher, G.; Czopf, L.; Fulop, A.; Battyany, I.; Sumegi, B.; Toth, K.; Szabados, E. Cardioprotection by resveratrol: A human clinical trial in patients with stable coronary artery disease. Clin. Hemorheol. Microcirc. 2012, 50, 179-187.

96. Bode, L.M.; Bunzel, D.; Huch, M.; Cho, G.S.; Ruhland, D.; Bunzel, M.; Bub, A.; Franz, C.M.; Kulling, S.E. In vivo and in vitro metabolism of trans-resveratrol by human gut microbiota. Am. J. Clin. Nutr. 2013, 97, 295-309. [CrossRef]

97. Marti, C.N.; Gheorghiade, M.; Kalogeropoulos, A.P.; Georgiopoulou, V.V.; Quyyumi, A.A.; Butler, J. Endothelial dysfunction, arterial stiffness, and heart failure. J. Am. Coll Cardiol. 2012, 60, 1455-1469. [CrossRef]

98. Patti, G.; Melfi, R.; Di Sciascio, G. The role of endothelial dysfunction in the pathogenesis and in clinical practice of atherosclerosis. Current evidences. Recenti Progress. Med. 2005, 96, 499-507.

99. Tousoulis, D.; Charakida, M.; Stefanadis, C. Inflammation and endothelial dysfunction as therapeutic targets in patients with heart failure. Int. J. Cardiol. 2005, 100, 347-353. [CrossRef]

100. Xia, N.; Forstermann, U.; Li, H. Effects of resveratrol on eNOS in the endothelium and the perivascular adipose tissue. Ann. N. Y. Acad. Sci. 2017, 1403, 132-141. [CrossRef] [PubMed]

101. Most, J.; Penders, J.; Lucchesi, M.; Goossens, G.H.; Blaak, E.E. Gut microbiota composition in relation to the metabolic response to 12-week combined polyphenol supplementation in overweight men and women. Eur. J. Clin. Nutr. 2017, 71, 1040. [CrossRef]

102. Mattagajasingh, I.; Kim, C.S.; Naqvi, A.; Yamamori, T.; Hoffman, T.A.; Jung, S.B.; DeRicco, J.; Kasuno, K.; Irani, K. SIRT1 promotes endothelium-dependent vascular relaxation by activating endothelial nitric oxide synthase. Proc. Natl. Acad. Sci. USA 2007, 104, 14855-14860. [CrossRef]

103. Superko, H.R. Hypercholesterolemia and Dyslipidemia. Curr. Treat. Options Cardiovasc. Med. 2000, 2, $173-187$. [CrossRef]

104. Saeed, A.; Feofanova, E.V.; Yu, B.; Sun, W.; Virani, S.S.; Nambi, V.; Coresh, J.; Guild, C.S.; Boerwinkle, E.; Ballantyne, C.M.; et al. Remnant-Like Particle Cholesterol, Low-Density Lipoprotein Triglycerides, and Incident Cardiovascular Disease. J. Am. Coll Cardiol. 2018, 72, 156-169. [CrossRef]

105. Indolfi, C.; De Rosa, S.; Colombo, A. Bioresorbable vascular scaffolds-basic concepts and clinical outcome. Nat. Rev. Cardiol. 2016, 13, 719-729. [CrossRef] [PubMed]

106. Hackam, D.G. Intensive reduction of low-density lipoprotein-cholesterol: Implications of recent trials. Am. J. Cardiovasc. Drugs 2006, 6, 367-371. [CrossRef]

107. Ford, E.S.; Ajani, U.A.; Croft, J.B.; Critchley, J.A.; Labarthe, D.R.; Kottke, T.E.; Giles, W.H.; Capewell, S. Explaining the decrease in U.S. deaths from coronary disease, 1980-2000. New Engl. J. Med. 2007, 356, 2388-2398. [CrossRef]

108. Perez-Mendez, O.; Pacheco, H.G.; Martinez-Sanchez, C.; Franco, M. HDL-cholesterol in coronary artery disease risk: Function or structure? Clin. Chim. Acta 2014, 429, 111-122. [CrossRef] [PubMed]

109. Chyou, J.Y.; Mega, J.L.; Sabatine, M.S. Chapter 4-Pharmacogenetics. In Cardiovascular Therapeutics: A Companion to Braunwald's Heart Disease, 4th ed.; Antman, E.M., Sabatine, M.S., Eds.; W.B. Saunders: Philadelphia, PA, USA, 2013; pp. 53-66. 
110. Stunkel, W.; Campbell, R.M. Sirtuin 1 (SIRT1): The misunderstood HDAC. J. Biomol. Screen. 2011, 16, $1153-1169$. [CrossRef]

111. Lasa, A.; Schweiger, M.; Kotzbeck, P.; Churruca, I.; Simon, E.; Zechner, R.; Portillo, M.P. Resveratrol regulates lipolysis via adipose triglyceride lipase. J. Nutr. Biochem. 2012, 23, 379-384. [CrossRef] [PubMed]

112. Rosenson, R.S.; Davidson, M.H.; Pourfarzib, R. Underappreciated opportunities for low-density lipoprotein management in patients with cardiometabolic residual risk. Atherosclerosis 2010, 213, 1-7. [CrossRef]

113. Georgiopoulou, V.V.; Kalogeropoulos, A.P.; Butler, J. Heart failure in hypertension: Prevention and treatment. Drugs 2012, 72, 1373-1398. [CrossRef] [PubMed]

114. Whelton, P.K.; He, J.; Muntner, P. Prevalence, awareness, treatment and control of hypertension in North America, North Africa and Asia. J. Human Hypertens. 2004, 18, 545-551. [CrossRef]

115. Vongpatanasin, W. Resistant hypertension: A review of diagnosis and management. Jama 2014, 311, $2216-2224$. [CrossRef] [PubMed]

116. Dolinsky, V.W.; Chakrabarti, S.; Pereira, T.J.; Oka, T.; Levasseur, J.; Beker, D.; Zordoky, B.N.; Morton, J.S.; Nagendran, J.; Lopaschuk, G.D.; et al. Resveratrol prevents hypertension and cardiac hypertrophy in hypertensive rats and mice. Biochim. Biophys. Acta 2013, 1832, 1723-1733. [CrossRef]

117. Liu, Z.; Song, Y.; Zhang, X.; Liu, Z.; Zhang, W.; Mao, W.; Wang, W.; Cui, W.; Zhang, X.; Jia, X.; et al. Effects of trans-resveratrol on hypertension-induced cardiac hypertrophy using the partially nephrectomized rat model. Clin. Exp. Pharmacol. Physiol. 2005, 32, 1049-1054. [CrossRef] [PubMed]

118. Toklu, H.Z.; Sehirli, O.; Ersahin, M.; Suleymanoglu, S.; Yiginer, O.; Emekli-Alturfan, E.; Yarat, A.; Yegen, B.C.; Sener, G. Resveratrol improves cardiovascular function and reduces oxidative organ damage in the renal, cardiovascular and cerebral tissues of two-kidney, one-clip hypertensive rats. J. Pharm. Pharmacol. 2010, 62, 1784-1793. [CrossRef] [PubMed]

119. Bola, C.; Bartlett, H.; Eperjesi, F. Resveratrol and the eye: Activity and molecular mechanisms. Graefe's Arch. Clin. Exp. Ophthalmol. 2014, 252, 699-713. [CrossRef] [PubMed]

120. Mannari, C.; Bertelli, A.A.; Stiaccini, G.; Giovannini, L. Wine, sirtuins and nephroprotection: Not only resveratrol. Med. Hypotheses 2010, 75, 636-638. [CrossRef] [PubMed]

121. Pallas, M.; Porquet, D.; Vicente, A.; Sanfeliu, C. Resveratrol: New avenues for a natural compound in neuroprotection. Curr. Pharm. Des. 2013, 19, 6726-6731. [CrossRef] [PubMed]

122. Wu, J.M.; Hsieh, T.C. Resveratrol: A cardioprotective substance. Ann. N. Y. Acad. Sci. 2011, 1215, $16-21$. [CrossRef] [PubMed]

123. Theodotou, M.; Fokianos, K.; Mouzouridou, A.; Konstantinou, C.; Aristotelous, A.; Prodromou, D.; Chrysikou, A. The effect of resveratrol on hypertension: A clinical trial. Exp. Ther. Med. 2017, 13, 295-301. [CrossRef]

124. Fogacci, F.; Tocci, G.; Presta, V.; Fratter, A.; Borghi, C.; Cicero, A.F.G. Effect of resveratrol on blood pressure: A systematic review and meta-analysis of randomized, controlled, clinical trials. Crit. Rev. Food Sci. Nutr. 2018, 1-14. [CrossRef]

125. Liu, Y.; Ma, W.; Zhang, P.; He, S.; Huang, D. Effect of resveratrol on blood pressure: A meta-analysis of randomized controlled trials. Clin. Nutr. 2015, 34, 27-34. [CrossRef]

126. Mentz, R.J.; Felker, G.M. Noncardiac comorbidities and acute heart failure patients. Heart Fail. Clin. 2013, 9, 359-367. [CrossRef]

127. Swan, J.W.; Anker, S.D.; Walton, C.; Godsland, I.F.; Clark, A.L.; Leyva, F.; Stevenson, J.C.; Coats, A.J. Insulin resistance in chronic heart failure: Relation to severity and etiology of heart failure. J. Am. Coll Cardiol. 1997, 30, 527-532. [CrossRef]

128. Seferovic, P.M.; Petrie, M.C.; Filippatos, G.S.; Anker, S.D.; Rosano, G.; Bauersachs, J.; Paulus, W.J.; Komajda, M.; Cosentino, F.; de Boer, R.A.; et al. Type 2 diabetes mellitus and heart failure: A position statement from the Heart Failure Association of the European Society of Cardiology. Eur. J. Heart Fail. 2018, 20, 853-872. [CrossRef] [PubMed]

129. Connelly, K.A.; Gilbert, R.E.; Liu, P. Treatment of Diabetes in People With Heart Failure. Can. J. Diabetes 2018, 42, S196-S200. [CrossRef] [PubMed]

130. Campbell, P.; Krim, S.; Ventura, H. The Bi-directional Impact of Two Chronic Illnesses: Heart Failure and Diabetes-A review of the Epidemiology and Outcomes. Card. Fail. Rev. 2015, 1, 8-10. [CrossRef] [PubMed]

131. Lehrke, M.; Marx, N. Diabetes Mellitus and Heart Failure. Am. J. Med. 2017, 130, S40-S50. [CrossRef] [PubMed] 
132. MacDonald, M.R.; Petrie, M.C.; Varyani, F.; Ostergren, J.; Michelson, E.L.; Young, J.B.; Solomon, S.D.; Granger, C.B.; Swedberg, K.; Yusuf, S.; et al. Impact of diabetes on outcomes in patients with low and preserved ejection fraction heart failure: An analysis of the Candesartan in Heart failure: Assessment of Reduction in Mortality and morbidity (CHARM) programme. Eur. Heart J. 2008, 29, 1377-1385. [CrossRef] [PubMed]

133. Jia, G.; Hill, M.A.; Sowers, J.R. Diabetic Cardiomyopathy: An Update of Mechanisms Contributing to This Clinical Entity. Circ. Res. 2018, 122, 624-638. [CrossRef]

134. Low Wang, C.C.; Hess, C.N.; Hiatt, W.R.; Goldfine, A.B. Clinical Update: Cardiovascular Disease in Diabetes Mellitus: Atherosclerotic Cardiovascular Disease and Heart Failure in Type 2 Diabetes Mellitus-Mechanisms, Management, and Clinical Considerations. Circulation 2016, 133, 2459-2502. [CrossRef]

135. Diabetes Canada Clinical Practice Guidelines Expert Committee; Connelly, K.A.; Gilbert, R.E.; Liu, P. Treatment of Diabetes in People With Heart Failure. Can. J. Diabetes 2018, 42, S196-S200.

136. Ezekowitz, J.A.; O'Meara, E.; McDonald, M.A.; Abrams, H.; Chan, M.; Ducharme, A.; Giannetti, N.; Grzeslo, A.; Hamilton, P.G.; Heckman, G.A.; et al. 2017 Comprehensive Update of the Canadian Cardiovascular Society Guidelines for the Management of Heart Failure. Can. J. Cardiol. 2017, 33, 1342-1433. [CrossRef]

137. Zinman, B.; Wanner, C.; Lachin, J.M.; Fitchett, D.; Bluhmki, E.; Hantel, S.; Mattheus, M.; Devins, T.; Johansen, O.E.; Woerle, H.J.; et al. Empagliflozin, Cardiovascular Outcomes, and Mortality in Type 2 Diabetes. New Engl. J. Med. 2015, 373, 2117-2128. [CrossRef] [PubMed]

138. Mahaffey, K.W.; Neal, B.; Perkovic, V.; de Zeeuw, D.; Fulcher, G.; Erondu, N.; Shaw, W.; Fabbrini, E.; Sun, T.; Li, Q.; et al. Canagliflozin for Primary and Secondary Prevention of Cardiovascular Events: Results From the CANVAS Program (Canagliflozin Cardiovascular Assessment Study). Circulation 2018, 137, 323-334. [CrossRef] [PubMed]

139. Baur, J.A.; Pearson, K.J.; Price, N.L.; Jamieson, H.A.; Lerin, C.; Kalra, A.; Prabhu, V.V.; Allard, J.S.; Lopez-Lluch, G.; Lewis, K.; et al. Resveratrol improves health and survival of mice on a high-calorie diet. Nature 2006, 444, 337-342. [CrossRef] [PubMed]

140. Jimenez-Gomez, Y.; Mattison, J.A.; Pearson, K.J.; Martin-Montalvo, A.; Palacios, H.H.; Sossong, A.M.; Ward, T.M.; Younts, C.M.; Lewis, K.; Allard, J.S.; et al. Resveratrol improves adipose insulin signaling and reduces the inflammatory response in adipose tissue of rhesus monkeys on high-fat, high-sugar diet. Cell Metab. 2013, 18, 533-545. [CrossRef] [PubMed]

141. Lagouge, M.; Argmann, C.; Gerhart-Hines, Z.; Meziane, H.; Lerin, C.; Daussin, F.; Messadeq, N.; Milne, J.; Lambert, P.; Elliott, P.; et al. Resveratrol improves mitochondrial function and protects against metabolic disease by activating SIRT1 and PGC-1alpha. Cell 2006, 127, 1109-1122. [CrossRef] [PubMed]

142. Szkudelski, T.; Szkudelska, K. Resveratrol and diabetes: From animal to human studies. Biochim. Biophys. Acta 2015, 1852, 1145-1154. [CrossRef] [PubMed]

143. Zhang, H.; Morgan, B.; Potter, B.J.; Ma, L.; Dellsperger, K.C.; Ungvari, Z.; Zhang, C. Resveratrol improves left ventricular diastolic relaxation in type 2 diabetes by inhibiting oxidative/nitrative stress: In vivo demonstration with magnetic resonance imaging. Am. J. Physiol. 2010, 299, H985-H994. [CrossRef]

144. Bresciani, L.; Calani, L.; Bocchi, L.; Delucchi, F.; Savi, M.; Ray, S.; Brighenti, F.; Stilli, D.; Del Rio, D. Bioaccumulation of resveratrol metabolites in myocardial tissue is dose-time dependent and related to cardiac hemodynamics in diabetic rats. Nutr. Metab. Cardiovasc. Dis. 2014, 24, 408-415. [CrossRef]

145. Movahed, A.; Nabipour, I.; Lieben Louis, X.; Thandapilly, S.J.; Yu, L.; Kalantarhormozi, M.; Rekabpour, S.J.; Netticadan, T. Antihyperglycemic Effects of Short Term Resveratrol Supplementation in Type 2 Diabetic Patients. Evid. -Based Complementary Altern. Med. 2013, 2013, 11. [CrossRef]

146. Brasnyó, P.; Molnár, G.A.; Mohás, M.; Markó, L.; Laczy, B.; Cseh, J.; Mikolás, E.; Szijártó, I.A.; Mérei, Á.; Halmai, R.; et al. Resveratrol improves insulin sensitivity, reduces oxidative stress and activates the Akt pathway in type 2 diabetic patients. Br. J. Nutr. 2011, 106, 383-389. [CrossRef]

147. Bashmakov, Y.K.; Assaad-Khalil, S.H.; Abou Seif, M.; Udumyan, R.; Megallaa, M.; Rohoma, K.H.; Zeitoun, M.; Petyaev, I.M. Resveratrol Promotes Foot Ulcer Size Reduction in Type 2 Diabetes Patients. ISRN Endocrinol. 2014, 2014, 8. [CrossRef]

148. Ozturk, E.; Arslan, A.K.K.; Yerer, M.B.; Bishayee, A. Resveratrol and diabetes: A critical review of clinical studies. Biomed. Pharmacother. 2017, 95, 230-234. [CrossRef] [PubMed] 
149. Liu, K.; Zhou, R.; Wang, B.; Mi, M.T. Effect of resveratrol on glucose control and insulin sensitivity: A meta-analysis of 11 randomized controlled trials. Am. J. Clin. Nutr. 2014, 99, 1510-1519. [CrossRef]

150. Ahmet, I.; Tae, H.J.; Lakatta, E.G.; Talan, M. Long-term low dose dietary resveratrol supplement reduces cardiovascular structural and functional deterioration in chronic heart failure in rats. Can. J. Physiol. Pharmacol. 2017, 95, 268-274. [CrossRef] [PubMed]

151. Wojciechowski, P.; Juric, D.; Louis, X.L.; Thandapilly, S.J.; Yu, L.; Taylor, C.; Netticadan, T. Resveratrol arrests and regresses the development of pressure overload- but not volume overload-induced cardiac hypertrophy in rats. J. Nutr. 2010, 140, 962-968. [CrossRef] [PubMed]

152. Matsumura, N.; Takahara, S.; Maayah, Z.H.; Parajuli, N.; Byrne, N.J.; Shoieb, S.M.; Soltys, C.M.; Beker, D.L.; Masson, G.; El-Kadi, A.O.S.; et al. Resveratrol improves cardiac function and exercise performance in MI-induced heart failure through the inhibition of cardiotoxic HETE metabolites. J. Mol. Cell. Cardiol. 2018, 125, 162-173. [CrossRef] [PubMed]

153. Rimbaud, S.; Ruiz, M.; Piquereau, J.; Mateo, P.; Fortin, D.; Veksler, V.; Garnier, A.; Ventura-Clapier, R. Resveratrol improves survival, hemodynamics and energetics in a rat model of hypertension leading to heart failure. PLoS ONE 2011, 6, e26391. [CrossRef]

154. Sung, M.M.; Byrne, N.J.; Robertson, I.M.; Kim, T.T.; Samokhvalov, V.; Levasseur, J.; Soltys, C.L.; Fung, D.; Tyreman, N.; Denou, E.; et al. Resveratrol improves exercise performance and skeletal muscle oxidative capacity in heart failure. Am. J. Physiol. 2017, 312, H842-H853. [CrossRef]

(C) 2019 by the authors. Licensee MDPI, Basel, Switzerland. This article is an open access article distributed under the terms and conditions of the Creative Commons Attribution (CC BY) license (http://creativecommons.org/licenses/by/4.0/). 